\title{
Laboratory cultivation and experimental studies of salinity effects on larval development in the African River prawn Macrobrachium vollenhovenii (Decapoda, Palaemonidae)
}

\author{
Jutta Willführ-Nast ${ }^{(1)}$, Harald Rosenthal ${ }^{(2)}$, Paul J. Udo ${ }^{(3)}$ and Friedrich Nast \\ (1) Biologische Anstalt Helgoland, Nothestrasse 31, D-2000 Hamburg 52, Germany. \\ (2) Institut für Meereskunde an der Universität hiel, Düsternbrooker W'eg 20, D-2300 Kìel I, Germanj)' \\ (3) University of Calabar, Dept. of Fisheries E Aquaculture, Institute of Oceanography, Calabar, Aigeria. \\ (4) Bundesamt für Seeschiffahrt und Hydrographie, Bernhard-Nocht-Strasse 78, D-2000 Hamburg 36, Germany.
}

Accepted January 12, 1993.

Willführ-Nast J., H. Rosenthal, P. J. Udo, F. Nast, Aquat. Living Resour., 1993, 6, 115-137.

Abstract

Larvae of the African River Prawn Macrobrachium vollenhovenii, indigenous to West Africa, were reared at various salinities $(0-32 \%$ ). A salinity range of $16-24 \%$ was found most suitable with highest survival and growth, and lowest number and duration of instars. Freshwater was lethal already to zoea I-larvae. A mass culture experiment demonstrated the aquaculture potential of this Macrobrachium species. Larval rearing to postlarvae was possible applying the same methods as for M. rosenbergii. Detailed descriptions of rearing techniques are provided.

Keywords: Prawns, Palaemonidae, Macrobrachium vollenhovenii, larval rearing, mass culture, salinity studies, egg incubation, survival, growth, larval and postlarval development.

Élevage en laboratoire et études expérimentales des effets de la salinité sur le développement larvaire de la crevette de rivière africaine Macrobrachium vollenhovenii (Decapoda, Palaemonidae).

Résumé

Les larves de la crevette de rivière africaine Macrobrachium vollenhovenii, espèce indigène d'Afrique de l'Ouest, ont été élevées à différentes salinités (0-32\%). Une gamme de salinités de 16-24\% a été considérée la plus appropriée pour des taux de croissance et de survie les plus importants, et pour des mues dont le nombre et la durée sont les plus faibles. L'eau douce était déjà létale pour les larves au stade zoe-I. Une expérience de culture en masse démontra la potentialité de l'aquaculture de cette espèce de Macrobrachium. L'élevage larvaire jusqu'aux postlarves était possible en appliquant les mêmes méthodes pour $M$. rosenbergii. Des descriptions détaillées des techniques d'élevage sont données.

Mots-clés : Crevettes, Palaemonidae, Macrobrachium vollenhovenii, élevage larvaire, élevage en masse, salinité, incubation des œufs, survie, croissance, développement larvaire et post-larvaires.

\section{INTRODUCTION}

During the "Second Workshop on the culture of Macrobrachium sp." held in 1976 (Hanson and Goodwin, 1977) the giant Malaysian prawn, Macrobrachium rosenbergii appeared to be the superior candidate for aquaculture of freshwater prawns. Other Macrobrachium species were considered inferior due to their slower growth rates, final sizes, lower fecundity and lower survival rates. Problems in larval rearing under artificial culture conditions were also considered more complex in species other than $M$. rosenbergii. It was 
suggested that alternative Macrobrachium species suitable for cultivation may be found in tropical Africa.

In West Africa, small seasonal commercial fisheries exist for freshwater shrimps, and some of these stocks were surveyed in 1952-1953 (Miller, 1971). The main target species for fisheries in this area is the relatively large freshwater shrimp Macrobrachium :ollenhorenii. An additional species, $M$. macrobrachion, is much smaller and of value only for the fisherman's own use.

The distribution of Macrobrachium rollenhozenii is confined to the West African coast. from Senegal to Angola (Holthuis, 1951). It is also found at the offshore islands of Cape Verde, Fernando Po and Saõ Tomé. This prawn grows to a total length (base of the eyestalk to the tip of the telson) of more than $150 \mathrm{~mm}$. with $200 \mathrm{~mm}$ for exceptional males (Miller, 1971). This author found gravid females from May to January, i.e. mainly in the rainy season, when the estuarine waters were extremely low in salinity. During the dry season. February to May, the waters are highly saline and. because the prawn avoids these higher salinities, the fishery on this species ceases. From model length analysis, Miller concluded that the growth rate of $M$. vollenhozenii was similar to that of $M$. rosenbergii, showing a rapid growth of juveniles and decreasing later. Furthermore, as he found no identifiable monthly modal length increase, Miller concluded that growth in adults was a function solely of food availability and not of age.

Fecundity ranged from 12.855 eggs per female in small prawns to 45.000 in large specimens (Miller. 1971). In a recent report. Udo and Ekpe (1991) determined the fecundity of 1,500 ovigerous females collected by shrimp fishermen in the Cross River estuary, when examining a much wider length interval. Their results agreed with Miller's data. and they expressed the relationship of fecundity $(F)$ and size (L) as log $\mathrm{F}=-4.5+2.7 \log \mathrm{L}$.

M. vollenhovenii is considered as a possible candidate for shrimp farming in Nigeria. It is assumed that it would become profitable at a much lower level of technology than other aquatic species. Because of its availability and lower cost, this native species is given preference over $M$. rosenbergii in the evaluation of commercial feasibility of prawn culture in this region.

One of the many prerequisites for a commercial prawn culture is the provision of "seedlings", i.e. the successful and predictable production of juveniles from eggs through all larval phases and metamorphosis. While the chances of survival in most decapod crustaceans are less than $0.1 \%$ in natural ecosystems (Bagenal, 1967), more than $50 \%$ can be achieved for $M$. rosenbergii reared under optimum laboratory conditions. For most other Macrobrachium species only poor larval survival has been reported (Mivajima, 1977). Among the specific requirements for successful larviculture are the following factors: (1) sufficient water supply of adaequate quality,
(2) provision of high protein food. (3) availability of waters of different salinity (always considered a key parameter for site selection). Temperature considerations seem to be of minor relevance in the tropics. While $M$. rosenbergii larvae show an optimum salinity range at 12-18\% (New, 1990) the salinity requirements for larval development of other Macrobrachium spp. are rarely reported. due to an "extreme ignorance of this genus in the wild" (Miyajima, 1977). Exceptions were provided by Read (1985) who investigated the ecology of larval development in $M$. petersi. and by Truesdale and Mermilliod (1979) studying growth of $M$. ohione in situ. Gray (1991 a.b) stressed the need for long-term studies after investigating the temporal variability in population variables of $M$. intermedium in a field study. Further field observations on different salinity requirements of the co-occurring species $M$. acanthurus and $M$. olfersii were reported by Gamba (1982) and Gamba and Rodriguez (1987) from eastern Venezuela. relating behavioural patterns to tidal regimes. Nevertheless. Salinity requirements appear to be species specific and may change during the life cycle (Choudhury, 1970. $1971 a, b, c$ ).

Unfortunately few published data have been related to the size of individuals. All authors generally refer to "gravid female size", but some authors measure it as length from the tip of the rostrum to the end of the telson. whereas others measure it from the base of the eye-stalk or the last rostral tooth, or simply report carapace length. This inconsistency makes comparisons of literature data on salinity iolerance in relation to size or number of eggs very unreliable.

In $M$. vollenhozenii. no information has been available on the incubation time of eggs, number of larval stages or moults, or on growth and survival. In a recent review by Zabi and Le Loeuff (1992, in press). an optimum temperature range of $25-33^{\circ} \mathrm{C}$ is quoted. but only for adults. Even reasonably reliable data on optimum salinities for various developmental stages cannot be obtained from field observations. Thereforc the present study addressed experimentally the question of optimum salinity requirements for early larval development of Macrobrachimm :ollenhoienii.

\section{MATERIAL AND METHODS}

In November 1989, three adult males and four adult females of $M$. rollenhorenii were caught in the Cross River estuary, near Calabar. Nigeria (4 $4^{\circ} 15^{\prime}$ $\left.4^{\circ} 45^{\prime} \mathrm{N}, 8^{\circ} 05^{\prime}-8^{\circ} 35^{\prime} \mathrm{E}\right)$. These specimens were air-shipped to the Biologische Anstalt Helgoland $(\mathrm{BAH})$. Hamburg, Germany. In the aquaculture laboratory: the animals were transferred to circular tanks of $0.4 \mathrm{~m}^{3}$ volume. Males and females were kept separate in small mesh wire cages to prevent cannibalism. The tanks were incorporated into a freshwater recirculating system of about $4.1 \mathrm{~m}^{3}$ volume. Water treatment was achieved by using a trickling filter and a settling 
tank (sump) to collect suspended solids. Runoff troughs also acted as settling basins from which solids were removed daily. Temperature was controlled by an immersion heater and a thermostat in the sump (range of $28.2-30.4^{\circ} \mathrm{C}$ ).

As no information on food requirements of adult prawns was available, three different diets were used: two commercial pelleted feeds: (1) a special test diet (AZ 30 sticks) provided by Tetra Comp. (Melle, Germany) successfully used to rear $M$. rosenbergii; (2) a product (Krebs-fit) by Interquell Comp. (Wehringen, Germany) composed for the European freshwater crayfish Astacus; and (3) fresh meat from the blue mussel (Mytilus edulis). All three diets were accepted by test specimens without preference.

In order to avoid biased results due to capture and transportation stress, ovigerous females were initially maintained through a complete moulting cycle, which lasted for about 37 days, allowing sufficient time for quarantining and acclimation.

After observing the pre-mating moult of a female, which normally took place in the very early morning hours, it was liberated from its cage, i.e. 3 to 6 hours after the pre-mating moult. A male was also set free to permit mating, followed by egg-laying within 24 hours back in its cage. At this early stage of development the colour of the eggs was orange-red. When the colour of the eggs changed to orangebrown after eight days, the female was gradually transferred to brackish water. The salinity was risen within 2-3 hours to $4 \%$ by dropwise addition of brackish water during the first, to $8 \%$ during the second, and to $12 \%$ during the third day. Salinities were obtained by dilution of full-strength North Sea water available from the recirculation system of the institute (Bulnheim, 1983; Rosenthal and Murray, 1986) with deionized water. After another 3 to 4 days the eggs had developed to the eye spot stage and their colour had changed to light grey-brown. The female remained at $12 \%$ salinity water until larvae hatched.

After hatching, the female was gradually readjusted to freshwater while the larvae were used for experiments. The egg incubation time was noted as the time interval between fertilization of spawned eggs and hatching. The total number of larvae was calculated from subsamples.

All length measurements were made from the basis of the eye-stalk to the tip of the telson, excluding uropods and spines. Live larvae were anaesthetised with MS 222 and measured under an inverse microscope (Utermöhl). To exclude possible later effects caused by this procedure, larvae were not returned to the experimental tank but preserved in $4 \%$ formaldehyde seawater solution (buffered with borax) for later morphological analysis.

Observations by Wickins (1972 a) and own experiences with $M$. rosentergii showed the well-known confinement-stress effect on individually reared prawns. Theretorc, a very high stocking density of
$150.1^{-1}$ was chosen for a mass culture experiment in order to explore the possibility of a hatchery success under commercially relevant conditions. As larval development and moulting periods can only be studied by direct observation of individuals, a dual experimental scheme was chosen. Larvae used in all experiments were produced by a single female $(10.5 \mathrm{~cm}$ total length, $30 \mathrm{~g}$ weight), but from several spawnings because it became gravid several times (within 19 to 47 days) during the experimental period of 5 months.

\section{Mass culture}

The "clearwater" technique (AQUACOP, 1977) was employed for the mass culture of larvae. This method had been modified after New and Singholka (1982) and was already successfully employed to rear large quantities of $M$. rosenbergii larvae in our laboratory since 1985 (Otte and Willführ. unpubl.).

The rearing vessel was a fibreglass tank of 301 volume. Its shape was cylindrical in the upper $30 \mathrm{~cm}$ part $(\varnothing$ of $35 \mathrm{~cm}$ ), while the lower $30 \mathrm{~cm}$ part became narrower conically to the bottom. Aerated from the bottom to keep larvae and feed suspended, the tank was connected to a 5001 recirculating system, using sand and gravel as a biofilter. The water inlet was installed at the bottom; the outflowing water passed through a pipe with a $150 \mu \mathrm{m}$ gaze at the surface. The flow was adjusted at 500 to $660 \mathrm{ml} \cdot \mathrm{min}^{-1}$. The water was completely exchanged twice during the 63 day experiment. Water quality parameters determined prior to and after the water change are given in table 1. All mass culture and salinity experiments were carried out in a room with controlled air temperature.

While water temperature was measured twice per day and salinity and $\mathrm{pH}$ once per day, other parameters were determined once a week. The total ammonium concentrations were determined by the indophenol method (Koroleff. 1970) modified by Meyer (pers. com.) to adjust for errors at higher salinities. Nitrite was determined by applying the sulfanilamid-naphthylamin-method. Temperature and salinity values were read with a WTW-Conductometer (LT2). Corrections for salinity values were obtained by aerometer readings calibrated with Copenhagen standard water.

The zoea larvae were fed the first time one day after hatching with fresh Artemia sp. nauplii hatched from San Francisco Bay brine shrimp eggs. since it was observed that zoea I larvae do not eat. During this initial period the lecithotrophic larvae are sustained by yolk cells visible in the proventriculus. In order to measure the initial growth and feeding activity in more detail, zoeal dry weight was determined $(n=125$ per sample in ZI and ZII. 50 in ZIII and ZIV, and 25 in ZV larvae). The larvae were rinsed 5 times in distilled water of low temperature $\left(4^{\circ} \mathrm{C}\right)$ in order to reduce activity, placed in 25 groups per stage 
Table 1. - Rearing trials with Mucrobrachium iollenhorenii larvae in different salinities: experimental design and environmental conditions ( $n$ : number of determinations: * after water change. ** before water change).

\begin{tabular}{|c|c|c|c|}
\hline \multirow{2}{*}{ Parameter } & \multirow{2}{*}{ Mass culture } & \multicolumn{2}{|c|}{ Salinity experiment } \\
\hline & & Series I & Series II \\
\hline Volume of culture vessel (1) & 30 & 0.050 & 0.050 \\
\hline Salinities $\left(\begin{array}{l}0 \\
100\end{array}\right)$ & 12 & $\begin{array}{c}8,10,12 \\
14,16\end{array}$ & $\begin{array}{l}0.12,16,20 \\
24.28,32\end{array}$ \\
\hline Temperature $\left({ }^{\circ} \mathrm{C}\right)$ & $\begin{array}{l}28.1 \pm 0.12 \\
(n=120)\end{array}$ & $\begin{array}{c}28.0 \pm 0.35 \\
(n=466)\end{array}$ & $\begin{array}{c}28.0 \pm 0.39 \\
(n=588)\end{array}$ \\
\hline $\mathrm{pH}$ (range) & $7.82-7.96$ & $\begin{array}{l}7.74-8.02^{*} \\
7.55-7.79 * *\end{array}$ & $\begin{array}{l}7.87-8.28^{*} \\
7.67-8.05^{* *}\end{array}$ \\
\hline $\mathrm{NO}_{2}^{-}\left(\mathrm{mg} . \mathrm{I}^{-1}\right)$ & $0.015-0.061$ & $\begin{array}{l}0.002-0.004^{*} \\
0.022-0.024^{* *}\end{array}$ & $\begin{array}{l}0.002-0.004^{*} \\
0.022-0.025^{* *}\end{array}$ \\
\hline $\mathrm{NH}_{4}^{+}\left(\mathrm{mg} \cdot 1^{-1}\right)$ & $0.035-0.125$ & $\begin{array}{c}0-0.01^{*} \\
0.332-0.392 * *\end{array}$ & $\begin{array}{c}0-0.006^{*} \\
0.336-0.385^{* *}\end{array}$ \\
\hline $\begin{array}{l}\text { Illumination }\left(\mu \mathrm{Em}^{-2} \mathrm{~s}^{-1}\right) \\
\text { Stocking density }\end{array}$ & $\begin{array}{c}12 \\
150(\text { zoeae } 1)\end{array}$ & $\begin{array}{c}10 \\
1 / \text { vial }\end{array}$ & $\begin{array}{c}10 \\
\text { 1.vial }\end{array}$ \\
\hline
\end{tabular}

on plastic films, dried for $24 \mathrm{hrs}$ at $60^{\circ} \mathrm{C}$, stored in a desiccator, and weighed on an ultra-micro balance (Sartorius, type 4431 MP8).

Larvae were fed in the early morning and late evening, ensuring a density of about 5 nauplii. $\mathrm{ml}^{-1}$. Prior to feeding, the actual concentration of Artemia nauplii was determined in a sample taken from the culture medium; the concentration was adjusted if necessary. From the fifth day, larvae were additionally fed with an artificial diet (AZ 30, Tetra Company, Melle. Germany) whereby the main raw components (according to data provided by the producer) were: protein $55 \%$, fat $16 \%$, ash $5 \%$, water $8 \%$ (remainder undetermined).

This diet was administered to the larvae depending upon acceptance. In the beginning, 200-500 $\mu \mathrm{m}$ size pellets were crushed manually and fed ad libitum during daytime (rations in 6 pinches, totalling $0.4 \mathrm{~g}$ per day). Brine shrimp nauplii were supplied only in the late evening. During later larval development, the quantity of artificial food was increased both in size (up to $1000 \mu \mathrm{m}$ ) and in frequency (to maximal $1.4 \mathrm{~g}$ per day, shared in 14 pinches, one of them given at night). This amount was greatly reduced prior to moulting, when larvae ceased feeding. Each morning and evening, remaining pellets, faeces and dead Artemia were siphoned off from the rearing tank.

Length measurements were started by sampling $n=50$ larvae. From day 7 , a sample size of $n=30$ larvae appeared sufficient. The samples were preserved in $4 \%$-formaldehyde-seawater solution buffered by borax ( $\mathrm{pH} 8 \pm 0.5)$.

This experiment was terminated by measuring and weighing 30 postlarvae; all remaining larvae were transferred to the following postlarval experiment.

We define "postlarvae" as the first juvenile stage characterized by significant changes in behaviour (from pelagic to semibenthic or benthic) and morphology (appearance of long flagellae in the antennae. reduction of the pereiopods exopods, and presence of functional biramous pleopods).

\section{Rearing of postlarvae (PL)}

In the mass culture, postlarvae occurred asynchronously. For further rearing, postlarvae were taken during the 9 th week after hatching. Within the last three days of the following fortnight. PLs were adapted to freshwater in steps of $3.5 \%$ reduction day. After weight measurements on the fourth day. $150 \mathrm{PL}$ were transferred into the same recirculating system as used for the adults $\left(28.3 \pm 0.2^{\circ} \mathrm{C}\right)$. They were kept in a round 1151 plexiglass tank (flow rate of $1.4-1.61 / \mathrm{min}$ ) in which 6 bundles of $24 \mathrm{dark}$ coloured PVC-tubes $(16 \mathrm{~cm}$ length. $1.3 \mathrm{~cm}$ in diameter) provided shelter. In our previous rearing experiments with $M$. rosenbergii postlarvae, this kind of shelter already had proven to reduce cannibalism. the greatest single cause of mortality in the rearing of laboratory populations of juveniles. Additional data on culture conditions is given in table 2.

PL were fed each day in the morning and evening alternately with chopped blue mussel (Mytilus edulis) flesh and artificial pellets (AZ30. see above, $1.5 \mathrm{~mm}$ diameter). The amount fed daily (Mytilus flesh at a level equal to $100 \%$ of estimated PL biomass, pellets $10 \%$ ) was determined initially: non-enten food and other debris were later siphoned off before the next feeding. The amount of food was adjusted every second week after measuring PL weight. Live weight was determined after removing individual prawns from the tank with a mesh strainer. PL were placed on absorbent tissue paper, gently dabbed, weighed on a Sartorius analytical balance. Length was determined under a dissecting microscope to the nearest $0.5 \mathrm{~mm}$. As PL often were observed to leave the water and sit outside on the tube walls. we also assumed that this measuring procedure did not harm them. 
Table 2. - Rearing conditions for Macrobrachium :ollenhorenii postlarvae (PL). Further details in text (length and weight: $\bar{x}=\mathrm{SD}$; chemical parameters: range given).

\begin{tabular}{ll}
\hline $\begin{array}{l}\text { Number of PL } \\
\text { stocked: }\end{array}$ & 150 \\
$\begin{array}{c}\text { Initial length: } \\
\text { Initial weight: }\end{array}$ & $10.5 \pm 0.79 \mathrm{~mm}$ \\
Tank volume: & $22.87 \pm 5.63 \mathrm{mg}$ \\
Illumination: & $115 \mathrm{l}$ \\
& $12 \mathrm{~h}$ dark, \\
& $11 \mathrm{~h} \mathrm{light}\left(1.65-1.7 \mu \mathrm{Em}^{-2} \mathrm{~s}^{-1}\right)$ at the water \\
& surface, $2 \times 0.5 \mathrm{~h} \mathrm{dim}\left(0.1-0.15 \mu \mathrm{Em}^{-2} \mathrm{~s}^{-1}\right)$ \\
$\mathrm{pH}$ at inflow: & $8.06-8.33$ \\
$\mathrm{pH}$ at outflow: & $8.15-8.39$ \\
$\mathrm{NO}_{2}^{-}$at inflow: & $0.002-0.021$ \\
$\mathrm{NO}_{2}^{-}$at outflow: & $0.002-0.022$ \\
$\mathrm{NH}_{+}^{+}$at inflow: & $0.000-0.042$ \\
$\mathrm{NH}_{4}^{-}$at outflow: & $0.008-0.078$ \\
\hline
\end{tabular}

\section{Salinity experiment, series I}

There were two observation periods in the entire salinity experiment: in the first series, the lower salinities were tested. in a second the higher ones. For each salinity in the first series $(8,10,12,14$ and $16 \%$ ), 50 vials with individual larvae were placed in a $28^{\circ} \mathrm{C}$ iemperature controlled room. The mean temperature in the vials was kept constant at $28.03 \pm 0.35^{\circ} \mathrm{C}$ $(\bar{x} \pm S D ; n=466)$. Vials used were open cylindrical $50 \mathrm{ml}$ polystyrol transparent vessels $(40 \mathrm{~mm} \varnothing$, $45 \mathrm{~mm}$ high. flat bottom). They were filled with $45 \mathrm{ml}$ of the respective test media, without applying aeration. Due to a high evaporation rate, salinity increased noticeably between water changes. Therefore, preliminary experiments were conducted to determine the rate of evaporation. In later experiments, the initial salinity was consistently kept slightly lower than the desired value in order to compensate for evaporation (table 3).

Table 3. - Rearing trials with larvae of Macrobrachium :ollenhovenii. Salinity variations in experimental vials between two subsequent water changes: temperature $=28.0 \pm 0.27^{\circ} \mathrm{C}(n=90)$ : salinities in ${ }_{100}$.

\begin{tabular}{ccc}
\hline Desired salinity & Initial salinity & Salinity after $24 \mathrm{~h}$ \\
\hline 8 & 7.70 & 8.20 \\
10 & 9.70 & 10.30 \\
12 & 11.65 & 12.35 \\
14 & 13.75 & 14.60 \\
16 & 15.65 & 16.65 \\
20 & 19.40 & 20.70 \\
24 & 23.50 & 25.10 \\
28 & 27.20 & 29.10 \\
32 & 31.10 & 33.30 \\
\hline
\end{tabular}

Salinities were checked with a hand-held conductometer and adjusted to the values given in table 3. Test media were aerated until they reached the experimental temperature. Prior to water change, temperature and salinity were checked again.

Freshly hatched larvae were first transferred to beakers with about $12 \%$ salinity water, then gradually acclimated drop-by-drop to the experimental salinities within two to four hours. Thereafter. the larvae were individually pipetted into the experimental vials.

Daily handling included the individual transfer of larvae into vials with new water, according to the details given above. Each larvae was fed in the early morning after the water exchange. The feed was solely brine shrimp at a density of 5 Artemia nauplii. $\mathrm{ml}^{-1}$.

Daily inspections for exuviae and dead larvae were conducted twice daily, in the early morning (between 7 and 8 a.m.) and in the evening (at 8 p.m.).

This experiment was terminated after 30 days, when zoea larvae began to jump out of the vials. Attempts to prevent this jumping by covering the vials failed, as larvae then stuck to the top, unable to return to their medium.

\section{Salinity experiment, series II}

The second series covered the higher salinities of 20, 24 and $28 \%$; the trials at 12 and $16 \%$ were repeated for comparison of series I and II. In addition, an experiment at $32 \%$, as well as one with freshwater, were run. The former was started seven days after hatching, using larvae in stages III-IV which were initially reared at $28 \%$; they were gradually adapted to this salinity over a two hour period. Details of experimental conditions are given in table 1 .

Because of higher experimental salinities, the female was transferred after fertilization to $20 \%$ instead of $12 \%$. Freshly hatched larvae were gradually adjusted to the required salinities as described above: $8 \mathrm{~h}$ for freshwater; 4 to $5 \mathrm{~h}$ for 12 and $28 \%$; $2.5 \mathrm{~h}$ for 16 and $24 \%$.

\section{RESULTS}

\section{Incubation time}

Egg incubation time for Macrobrachium rollenhorenii at $28.2-30.4^{\circ} \mathrm{C}$ was 13 to 14 davs (based on 4 records: table 4). Additional 6 records from other females maintained in the same culture system ranged 
from 13 to 16 days. The results indicate an increasing fecundity with increasing size.

Table 4. - Fecundity and incubation time in relation to size of hacrobrachium iollenino:enii females.

\begin{tabular}{cccc}
\hline $\begin{array}{c}\text { Total } \\
\text { length }(\mathrm{cm})\end{array}$ & $\begin{array}{c}\text { Wet } \\
\text { weight }(\mathrm{g})\end{array}$ & $\begin{array}{c}\text { Incubation } \\
\text { time }(\mathrm{d})\end{array}$ & $\begin{array}{c}\text { No. of } \\
\text { larvae }\end{array}$ \\
\hline 8.1 & 13.0 & 14 & 13.670 \\
8.1 & 13.5 & 14 & 15.400 \\
10.0 & 28.5 & 13 & 44.430 \\
10.5 & 30.0 & 14 & 43.680 \\
\hline
\end{tabular}

\section{Mass culture}

Initially, 4,500 zoea I-larvae (ZI) were stocked in mass culture. Total body lengths ranged from 1.42 to $1.58 \mathrm{~mm}$, showing the smallest length deviation throughout $(\bar{x}=1.53 \pm 0.04 \mathrm{~mm})$. The larvae swam actively around in the Macrobrachium-typical style in an inverted position. with their ventral side exposed to the surface, and swimming backwards. They then began to form loose groups, mostly in the upper quarter of the water-column. Observations were aggravating by the very few pigmentations at this larval stage and the still absent brown-orange colour later caused by the consumption of brine shrimp nauplii. Larvae began feeding only after moulting to the zoea II-stage (ZII). The ZII could easily be identified by their stalked eyes, in contrast to the sessile eyes of the ZI.

In order to ascertain the onset of feeding, the dry weights of 25 larvae in stages $\mathrm{ZI}$ to $\mathrm{V}$ were determined. The results ( $f i g .1$ ) clearly indicate that ZI-larvae did not feed at all, but exclusively absorbed yolk. losing about $30 \%$ of their body weight within about

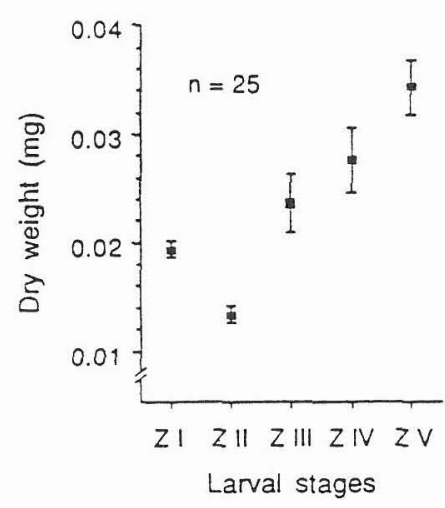

Figure 1. - Growth (dry weight) of Macrobrachitum iollenhozenii larvae (ZI-ZV) reared in mass culture. Mean values are based in each larval stage on 25 weight measurements $(n)$. with 5 individuals each in the zoea I and II. 2 in the zoea III and IV. and $I$ in the zoea $V$ stage. Error bars: $\bar{x} \pm S D$. three days, After the first moult. the ZII-larvie revealed Artemia in their stomach: a weight gain of $77 \%$ was observed after the second moult $(22 \%$ gain in relation to the initial ZI weight). The ZlII-larvae moulted to the next stage after another three days. with an increment of $17 \%$; the fourth moulted with a $24.5 \%$ increase in dry weight. Following Brook's Rule of a species-specific growth increment. this should be about $20 \%$ in early larval stages (ZI-ZV) of Macrobrachium rollenhorenii.

A starvation experiment confirmed that only the ZI stage develops without food: 20 ZI-larvae were kept individually in vials at $28.5^{\circ} \mathrm{C}$ and $12^{\circ} \%$ salinity without food. First moulting occurred after 2 days in $15 \%$ of the larvae, another $30 \%$ moulted after 3 days. and further $15 \%$ after 4 days. The remaining $40 \%$ died before moulting to the second zoea. All ZIIlarvae died with the absence of food in $2-5$ days. without moulting to the next stage.

The ZIII-larvae in the mass culture rearing experiment were identified by the appearance of uropods with separated exopodits. whereas the ZIV revealed free exo- and endopodit with setae and a very broad telson tip. The $\mathrm{ZV}$ differed in their longitudinally enlarged telson. with the proximal margin (basis) narrower than the distal margin (tip of the telson). So far. larval development was similar to that in $M$. rosenbergii. However, ZVI-larvae did not yet reveal pleopod buds. only the telson became more elongated. The moults that followed were not associated with further morphological development. Hence. stage duration was not further considered in this mass culture experiment.

In this experiment growth in terms of length increase was measured daily, and after the 25 th day every second day. The first postlarvae (PL) appeared after 47 days. The experiment was continued to the 63 rd day (referred to as the $60 \%$ PL drop time), when $60 \%$ of the larvae completed metamorphosis and sat at the walls of the tank. behaving in swimming and in locomotion like the adults. In total, 462 postlarvae (i.e. about 12\%) settled in the mass culture (after subtraction of samples taken for length and dry weight determinations). Within 63 days, the larvae grew continuously from $1.53 \pm 0.04 \mathrm{~mm}$ to a postlarval length of $8.31=0.26 \mathrm{~mm}$ (carapace length $2.26 \pm 0.11 \mathrm{~mm}$ ). with increasing variability (fig. 2$)$ : Mean lengths and relative variability $\left(s^{2}, \bar{x}\right)$ were very highly significantly positive correlated $(r=0.83$. $p<0.001$ ).

At the second and third day after hatching. the random sample showed that $70 \%$ had moulted to the ZII-stage. with a size of $1.61 \pm 0.036 \mathrm{~mm}$ length. The relative increment expressed as the percentage increase of the pre-moult length is thus calculated as 5.85 for this first moult. The remaining ZI-larvae still had their initial size of $1.52 \pm 0.067 \mathrm{~mm}$ length. ZI-larvae were found up to the fourth day at a rate 


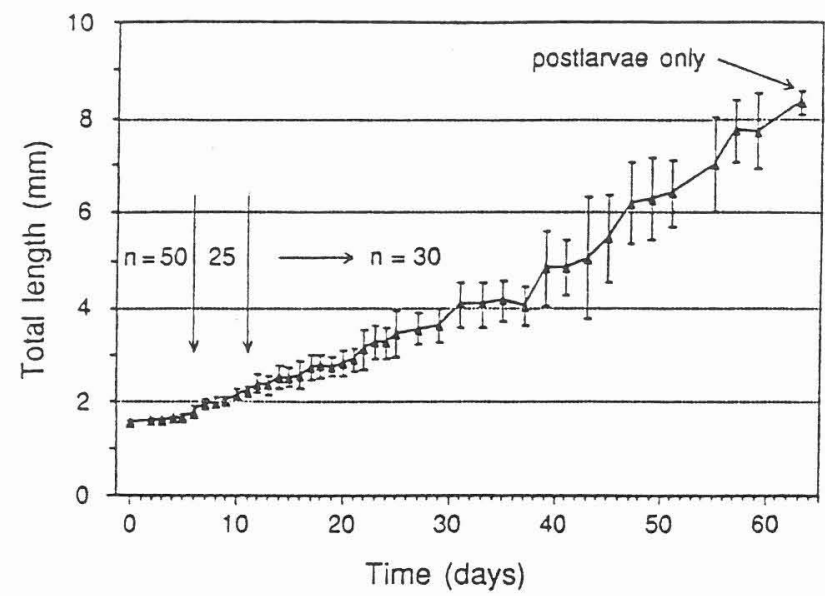

Figure 2. - Growth (total length) of Macrobrachium rollenhozenii in mass culture. Salinity $=12 \%$; temperature $=28^{\circ} \pm 0.1^{\circ} \mathrm{C}$; initial density 150 larvae $/ 1$ (30 I tank $=4500$ larvae); $n=$ number of determination; arrows indicate date at which sample size was changed; error bars: $\bar{x} \pm \mathrm{SD}$.

of $20 \%$. These ones are suspected to fail first moulting, thus losing $1 / 5$ by initial mortality.

The relative ( $\%$ of premoult size) increment was in general about $10 \%$ in each moult. It was conspicuously higher only in the moult of the first feeding state, i.e. ZII to ZIII (fig. 3).

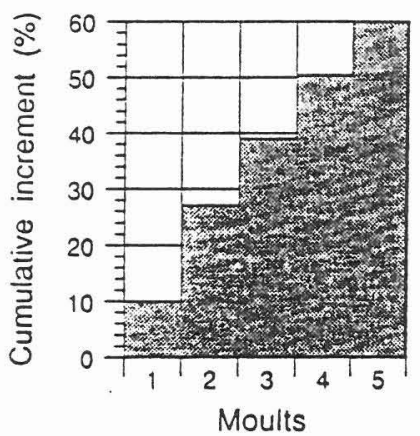

Figure 3. - Relative length increment ( $\%$ of premoult size) per moult of early larval stages (moults 1 to 5) in .Macrobrachium vollenhorenii.

Variability increased not only in larval size, but also in the duration of subsequent instars (fig. 4). For instance, some ZIII were still observed on day 13 when the first ZVII already appeared, so that up to five different stages occurred together in mass culture. They formed distinguishable size groups (table 5) and could also be separated morphologically.

However, during the following 50 days growth could only be traced in the average of length increase per day and not by individual moults or stages ( fig. 5). As the first seven moults could be traced

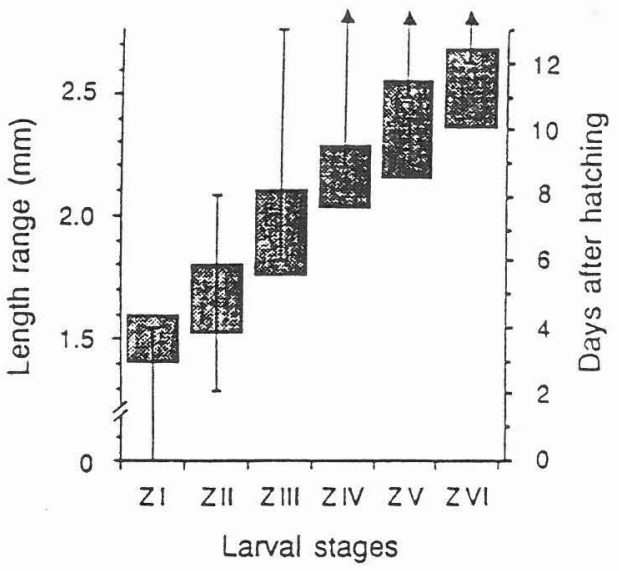

Figure 4. - Mass rearing of Macrobrachitum :ollenhoienii. Overlap in length (bars) and developmental time (lines) of zoeal stages during the initial 13 days of rearing.

Table 5. - Larval stage composition (\%) and length range of Macrobrachium zollenhorenii in mass culture at the 13 th day after hatching, $n=30$ individuals.

\begin{tabular}{lccccc}
\hline \multicolumn{1}{c}{ 13th day } & ZIII & ZIV & ZV & ZVI & ZVII \\
\hline $\begin{array}{l}\text { Stage composition } \\
(\%)\end{array}$ & 6.7 & 23.3 & 26.7 & 40.0 & 3.3 \\
Length range $(\mathrm{mm})$ & $1.88-1.98$ & $2.1-2.28$ & $2.23-2.38$ & $2.36-2.58$ & 2.88 \\
\hline
\end{tabular}

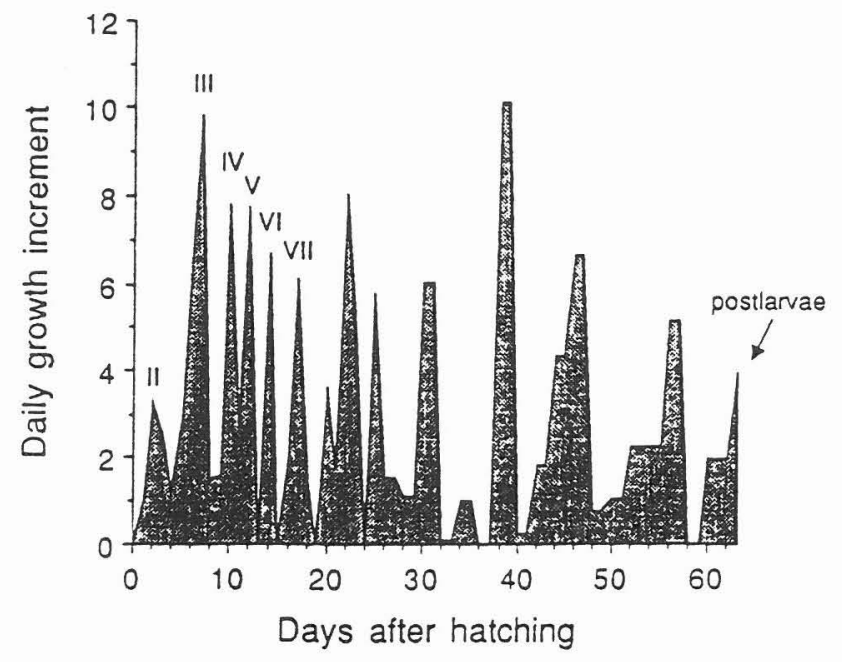

Figure 5. - Mass culture of Macrobrachium :ollenhowenii larvat until metamorphosis (63 days). Daily growth increment, which is the percentage gain in length over the previous day. Only zoeal stages II-VII morphologically identifiable.

morphologically, the first seven peaks can clearly be attributed to consecutive larval stages. Also interpreting each following peak as another moult. this plot 
suggests about 8 more instars, i.e. a total of 14 larval stages. The last (15th) peak represents postlarvae.

With an increasing frequency of postlarvae (PL), it became evident that PLs showed a smaller size than did the biggest larvae ( 7.83 to 8.78 vs. 8.73 to $9.53 \mathrm{~mm}$ ). This observation also becomes obvious in the exponential growth curve (fig. 6), where the data points for the PL fall beneath the theoretical curve.

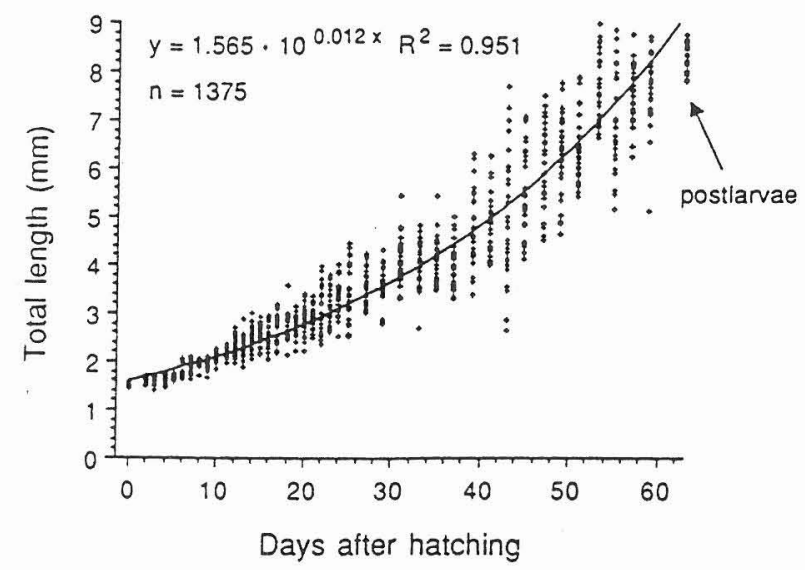

Figure 6. - Growth (length) of Macrobrachium vollenhozenii in mass culture, expressed as an exponential function of developmental time (days); $n=$ total number of measurements, arrow = postlarvae, note: smaller than predicted.

As measurements of larval total length (TL) were technically difficult and not precise due to the bend in body shape which resulted in a two-portion measurement, parallel carapace length (CL) measurements (length between the base of the eye-stalk and the posterior margin of the carapace) were also conducted. Plotting CL(Y) against TL(X) of larvae (excluding PLs) yielded a significant linear relationship (fig. 7).

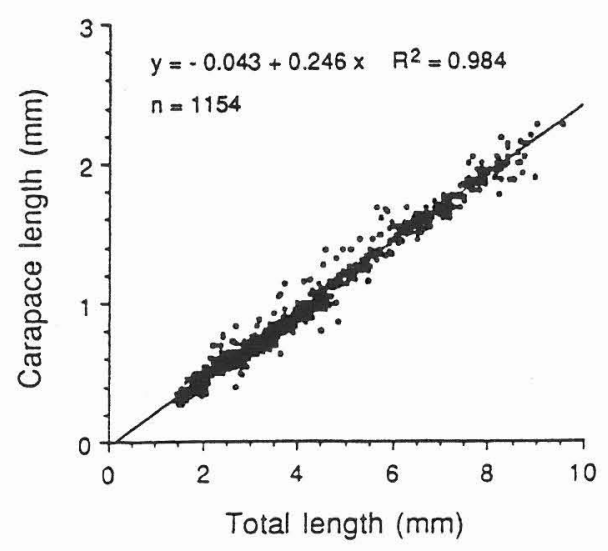

Figure 7. - Relationship between total length and carapace length in larvae of Macrobrachium iollenhozenii reared in mass culture. $n=$ number of determinations.
The unexpected long larval phase and the probable occurrence of "supernumerary moults" (without morphological change) pointed to an effective negative feedback in the larval development, giving rise to the suggestion of sub-optimal conditions of which salinity may be one factor. This was tested in more detail in the following experiments.

\section{Salinity experiments}

Surivial

In contrast to mass culture observations, salinity tests were made with individually kept animals to follow their daily survival. Total survival rates and duration differed considerably among salinities (fig. 8). As parallel salinity trials conducted with both series I and II at 12 and $16 \%$ showed practically no differences $(12-12 \%: t=1.266, n=31, p>0.05$; $16-16 \%: t=0.115 . n=31$ for paired observations, $p>0.05$ ), the data from the two series were pooled.

High survival rates were found at $12-28 \%$, with an optimal range from 14 to $24 \% / 00(\geqslant 82 \%)$. Again, these trials were only run for a month, because individuals started to jump out of their vials. Poorest survival occurred in freshwater, where no individual reached the second zoea; all died within 3-6 days. Salinities of 8 and $10 \%$ caused mortalities of about $60 \%$ within the first third of the experiment. Thereafter, most of the remaining larvae survived until the end of the experiment. Full-strength seawater also appeared inadaquate for larval development, since only $22 \%$ survived the first two weeks, and only $16 \%$ to the end of the experiment. In this high salinity, 12

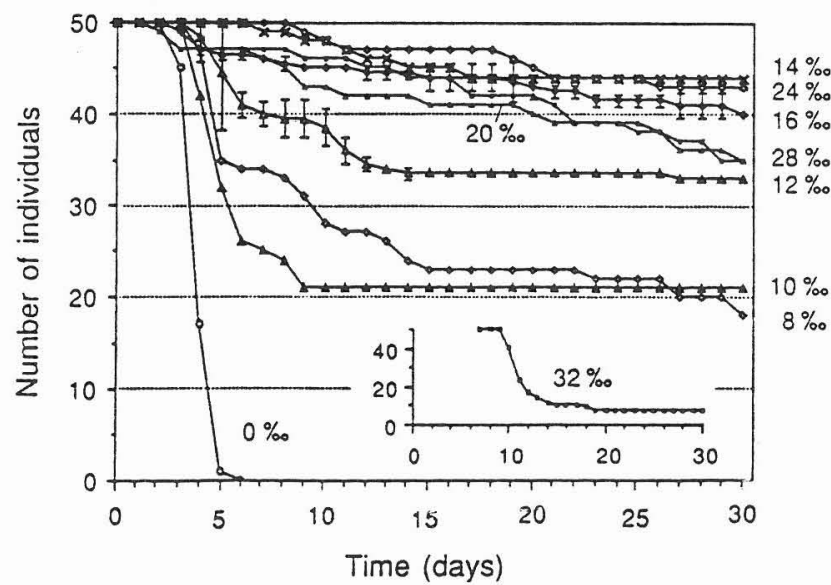

Figure 8. - Survival of Macrobruchium collenhutenii larvae reared individually in 10 different salinities, each trial with $n=50$ individuals. Observations for 30 days, except for $32 \%$ which were started 7 days after hatching.

and 13 moults were observed, in contrast to 814 moults at $14 \%$; therefore frequency of moulting must also be considered. 
Moulting frequency and duration of intermoult periods (IP)

Figure 9 shows the sequence and duration of larval stages in different salinities during the first 30 days of development (two experimental series I and II; see Material and Methods section). ZI-larvae did not moult in freshwater and died within five days. At salinities $\geqslant 8 \%$, ZI-larvae began to moult one day after hatching, with mass moulting on the second and third day. These larvae continued to moult every 24 days, yielding a maximum of 14 instars in 30 days. A few exceptional individuals moulted to a 15 th stage.
Significant differences were found (table 6) when the numbers of individuals reaching stage XIV in different salinities were compared. In one case $(16 \%$ ) a significant difference was also found between two experiments with identical conditions $\left(\hat{\chi}^{2}=4.34\right.$; $p<0.05$ ), in series I and II.

The two series were therefore considered separately. In the first series, the number of larvae reaching stage XIV was positively correlated with salinity between 8 and $16 \%$ oo $(r=0.971, p<0.01)$. In series II this increase can also be seen. however, with an inverse tendency at salinities $>24 \%$ ( fig. 10). In the

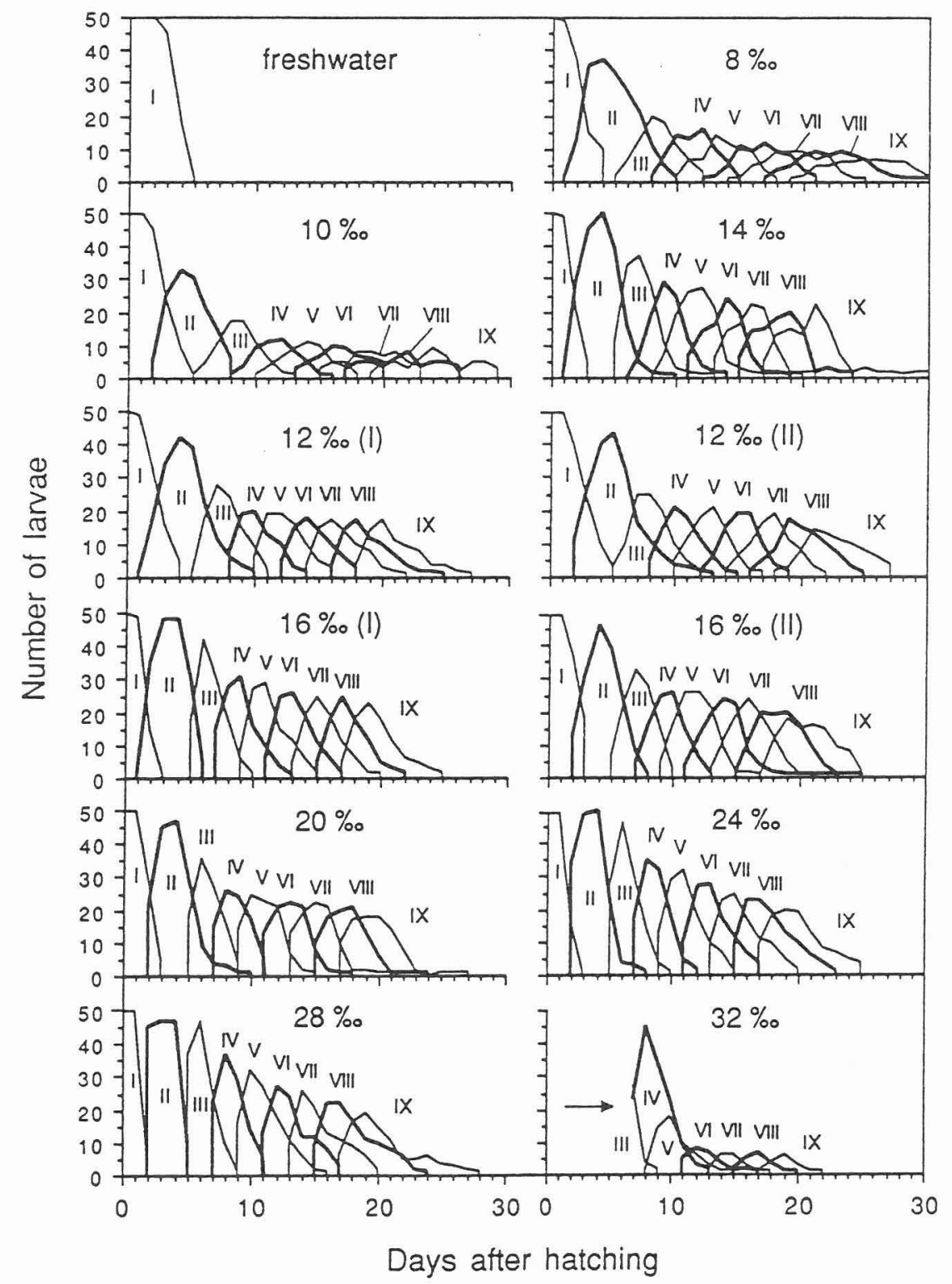

Figure 9. - Sequence and duration of Macrobrachium :ollenhotenii larval stages zoea I-IX reared individually in 10 different salinities with 12 and $16^{\circ}, 00$ in both series. initially started with $n=50$ larvae for each salinity. $\rightarrow$ Salinity trial $32^{\circ}, 00$ started 7 days after hatching. 
Table 6. - Number of Macrobrachium zollenho:enii larvae $(n)$ reaching stage XIV in different salinities. Comparisons by $\chi$-square analysis (n.s.: not significant. ${ }^{*} p<0.05 .{ }^{* *} p<0.01,{ }^{* * *} p<0.001$ ).

\begin{tabular}{rccccccccccccc}
\hline \multicolumn{10}{c}{ Series I } & \multicolumn{11}{c}{ Series II } \\
\hline$n$ & $\left.\begin{array}{c}\text { Salinity } \\
(\%\end{array}\right)$ & 10 & 12 & 14 & 16 & $n$ & $\begin{array}{c}\text { Salinity } \\
(\% 00)\end{array}$ & 16 & 20 & 24 & 28 & 32 \\
\hline 1 & 8 & n.s. & $* *$ & $* * *$ & $* * *$ & 6 & 12 & $*$ & $* *$ & $* *$ & $*$ & n.s. \\
2 & 10 & & $* *$ & $* * *$ & $* * *$ & 13 & 16 & & n.s. & n.s. & n.s. & $*$ \\
13 & 12 & & & n.s. & $*$ & 16 & 20 & & & n.s. & n.s. & $* *$ \\
15 & 14 & & & & $*$ & 17 & 24 & & & & n.s. & $* *$ \\
23 & 16 & & & & & 13 & 28 & & & & & $*$ \\
& & & & & 5 & 32 & & & & & \\
\hline
\end{tabular}

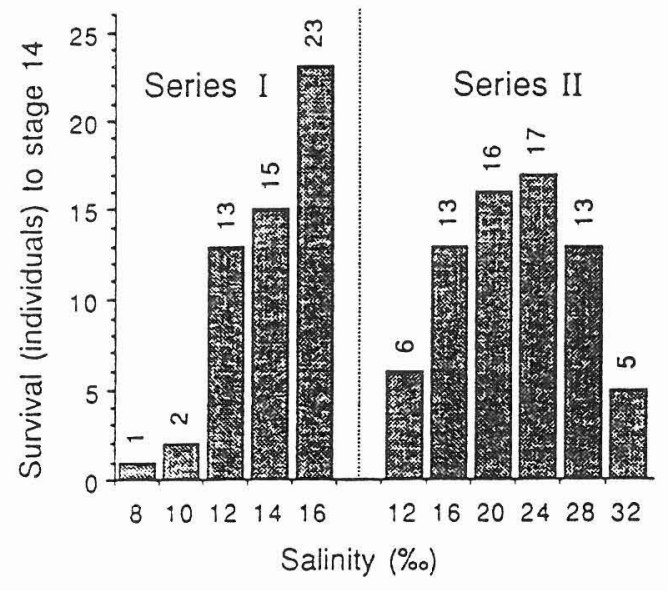

Figure 10. - Number of Macrobrachium :ollenhovenii larvae surviving to stage XIV (reared individually with initial $n=50$ ) in different salinities.

matrix of table 6 there is an area of non-significant differences between 16 and $28 \%$, suggesting that this range of salinities was most suitable, with similar survival. This can also be seen in figure 10, where 16 and $24 \% 0$ are the best in these two series, respectively.

Analysis of data was restricted to animals surviving the 30 days of the observation. Animals that died in the course of these experiments already showed longer average IP than did survivors $(p<0.05$ for ZII in the first series, not significant in the second, except in $12 \%$ ).

The mean IP for each stage and salinity is given in table 7. As some larvae had not moulted to the tenth stage when the experiment was terminated, IPs can only be compared until the ninth stage. The $32 \%$ experiment is not considered here, as just 8 larvae survived in this medium.

The IP for individual stages appears to decrease with increasing salinity. disguised by much variability. This decrease is most pronounced in the first series with ZII-larvae (fig. 11). It is also continuous in the second series-but there is an increase at the high salinities of 24 and $28 \%$. The same is true for the older stages, whereby in the second series a U-shaped form of decreasing IPs to $20 \%$, as well as an increase at 24 and $28 \%$, can be generally followed.

It was tested by means of $\chi$-square analyses. whether the IP was influenced by salinity stress. For these tests, the IP data were categorized in two groups: "regular" (2 days), or "prolonged" IP ( $\geqslant 3$ days); as an exception, 3 and $\geqslant 4$ days were chosen in the ZII, because this stage lasted longer on the average. In the first series, the result showed little statistical separateness among comparisons. as significant $\left(\hat{\chi}^{2}>2.706\right.$ for $\left.p<0.05\right)$ numbers varied without any tendency between stages (fig. 12. upper graph). The second series showed clear salinity effects $(p<0.05)$ in stages ZI-III with prolonged IPs occurring more frequently, whereas no significant IP differences were found in the higher stages. This indicates that the early stages are more sensitive to salinity stress than the later stages.

Rates of development are summarized in linear regression lines (computed from all available data; figure 13). Their slopes did not differ statistically $(t$-tests; $p>0.05)$; however, the mean time to reach larval stage IX clearly decreased with increasing salinity (table 8).

In summary, the salinity range from $16-28 \%$ appeared most favourable, allowing fastest development in Macrobrachium vollenhorenii larvae.

\section{Growth}

Reduction of growth caused by low salinities was pronounced only in series I (fig. 14). Growth in the different salinities may be ranked with $t$-tests as follows:

$$
8<10=12=14<16 \%
$$

that is, at $8 \%$ larvae were significantly shorter than those kept at $10 \%$; these did not differ significantly from those at 12 or $14 \%$, and larvae at $16 \%$ showed greatest length.

In the second series. mean length was at $28 \%$ significantly shorter than at 20 and $24 \% 00(p<0.05)$. 
Table 7. - Intermoult periods (IP: $\bar{x} \pm$ SD): number of observations (n) of Lacrabrachitum : ollenhoienii larvae held individually in eight different salinities (only individuals surviving at least 30 days included).

\begin{tabular}{|c|c|c|c|c|c|c|c|c|c|c|c|c|c|c|c|c|c|}
\hline \multirow{2}{*}{$\begin{array}{c}\text { Salinity } \\
(\%)\end{array}$} & \multirow{2}{*}{$n$} & \multicolumn{2}{|c|}{ IP I } & \multicolumn{2}{|c|}{ IP II } & \multicolumn{2}{|c|}{ IP III } & \multicolumn{2}{|c|}{ IP IV } & \multicolumn{2}{|c|}{ IP V } & \multicolumn{2}{|c|}{ IP VI } & \multicolumn{2}{|c|}{ IP VII } & \multicolumn{2}{|c|}{ IP VIII } \\
\hline & & $\bar{x}$ & SD & $\bar{x}$ & $\mathrm{SD}$ & $\bar{x}$ & SD & $\bar{x}$ & SD & $\bar{x}$ & SD & $\bar{x}$ & $\mathrm{SD}$ & $\bar{r}$ & $S D$ & $\bar{x}$ & SD \\
\hline \multicolumn{18}{|c|}{ Series I } \\
\hline 8 & 17 & 2.29 & 0.59 & 4.82 & 1.01 & 2.94 & 0.66 & 2.65 & 0.49 & 2.65 & 0.49 & 2.59 & 0.51 & 2.59 & 0.51 & 3.00 & 0.71 \\
\hline 10 & 21 & 2.86 & 0.73 & 4.52 & 0.81 & 3.33 & 0.66 & 2.48 & 0.51 & 2.52 & 0.51 & 2.48 & 0.51 & 2.48 & 0.51 & 2.33 & 0.48 \\
\hline 12 & 33 & 2.73 & 0.72 & 3.97 & 0.77 & 2.85 & 0.51 & 2.21 & 0.48 & 2.24 & 0.44 & 2.06 & 0.24 & 2.15 & 0.4 & 2.12 & 0.33 \\
\hline 14 & 44 & 2.39 & 0.62 & 3.70 & 0.55 & 2.66 & 0.61 & 2.18 & 0.54 & 2.48 & 0.73 & 2.14 & 0.35 & 2.16 & 0.37 & 2.23 & 0.42 \\
\hline 16 & 41 & 2.22 & 0.48 & 3.49 & 0.55 & 2.49 & 0.68 & 2.32 & 0.52 & 2.20 & 0.51 & 2.17 & 0.38 & 2.10 & 0.30 & 2.07 & 0.26 \\
\hline \multicolumn{18}{|c|}{ Series II } \\
\hline 12 & 33 & 3.06 & 0.93 & 4.15 & 0.97 & 2.82 & 0.46 & 2.15 & 0.44 & 2.39 & 0.66 & 2.33 & 0.48 & 2.30 & 0.47 & 2.45 & 0.51 \\
\hline 16 & 38 & 3.13 & 0.81 & 3.37 & 0.59 & 2.37 & 0.49 & 2.08 & 0.27 & 2.26 & 0.45 & 2.24 & 0.43 & 2.13 & 0.34 & 2.29 & 0.46 \\
\hline 20 & 35 & 2.66 & 0.64 & 3.03 & 0.45 & 2.37 & 0.60 & 2.14 & 0.36 & 2.23 & 0.49 & 2.17 & 0.38 & 2.14 & 0.36 & 2.31 & 0.47 \\
\hline 24 & 43 & 2.35 & 0.53 & 3.26 & 0.66 & 2.37 & 0.49 & 2.19 & 0.45 & 2.26 & 0.44 & 2.21 & $0 .+1$ & 2.16 & 0.37 & 2.33 & 0.61 \\
\hline 28 & 35 & 2.03 & 0.17 & 3.20 & 0.41 & 2.60 & 0.65 & 2.31 & 0.53 & 2.34 & 0.59 & 2.29 & 0.57 & 2.37 & 0.49 & 2.43 & 0.50 \\
\hline
\end{tabular}
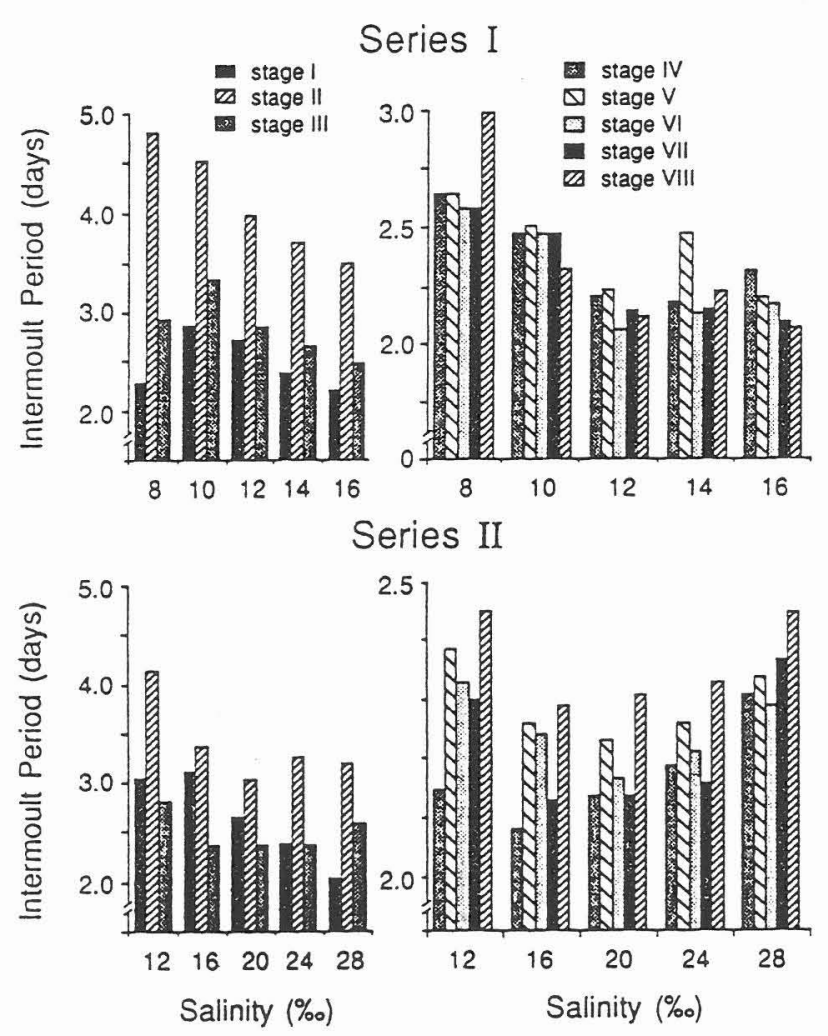

Figure 11. - Mean internoult periods (days) of individual larvae stages of Macrobrachium rollenhovenii reared in different salinities (two experimental series; data grouped in early and later larval stages). Numbers and standard deviations given in lable 6.

Larvae kept at $32 \%$ had the highest mortality $(84 \%)$, but the few survivors grew better than those at $28 \%$. However, they also showed reduced activity and probably would have failed to reach metamorphosis.

The stage composition at the end of the experiment is given in table 9, their length in figure 14 . With the
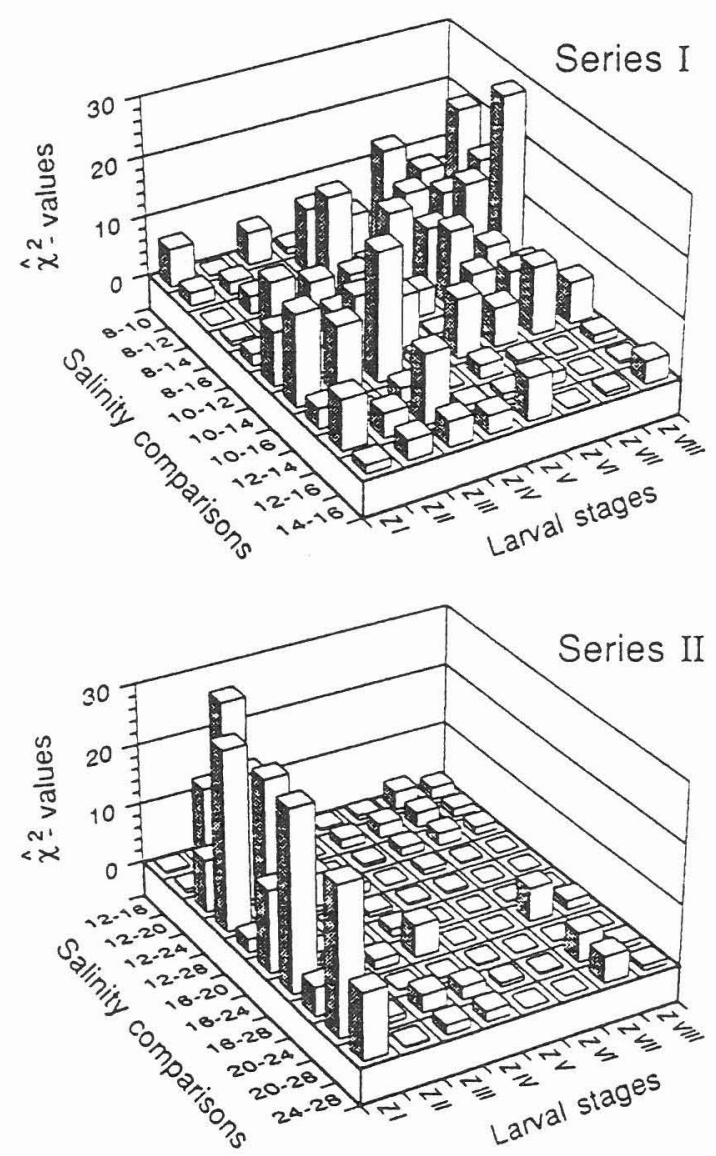

Figure 12. - Comparison ( $\bar{\chi}^{2}$-values) between intermoult periods (IPs) of Macrobrachium iolleninoienii larvae reared in different salinities (two series). IP data categorized in two groups. as 2 or more than 2 days. (except in the Zoea II with 3 or more than 3 day's). $\bar{\chi}^{2}$-values $>2.7$ statistically significant $(p<0.05)$. indicating salinity effects on IP.

increase in salinity. a higher frequency of later stages could be seen in the first series. While in the second 

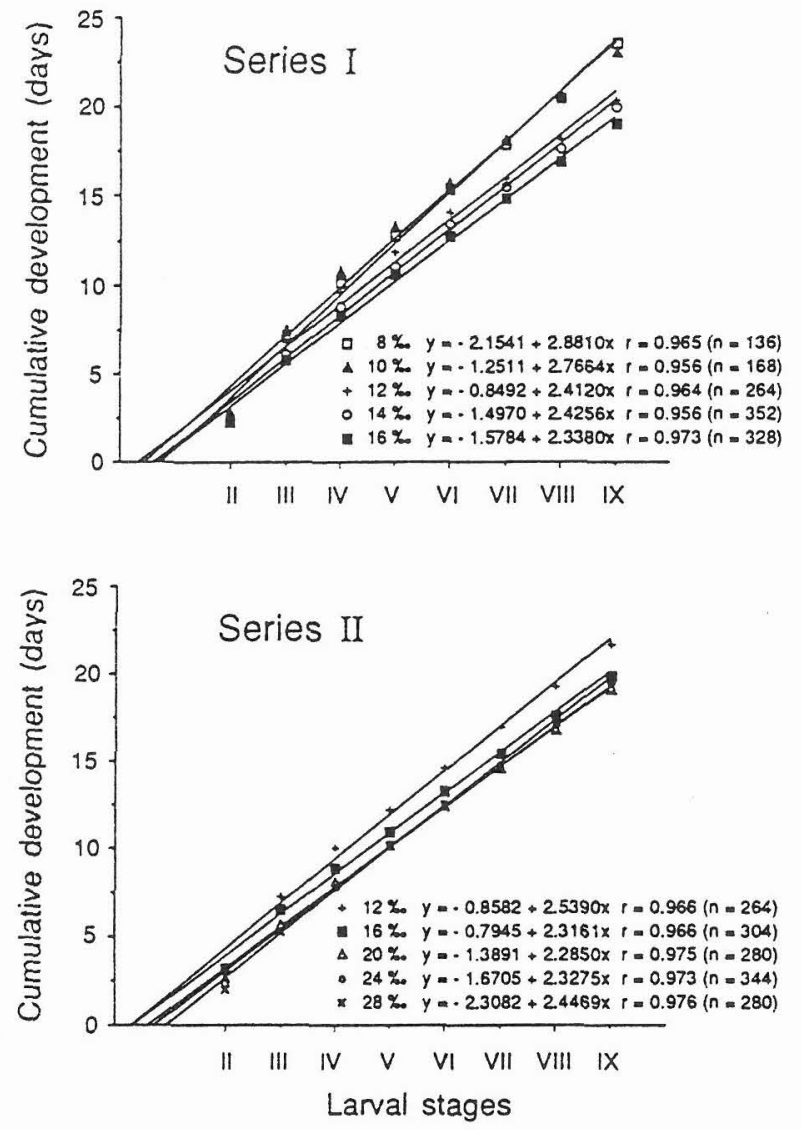

Figure 13. - Cumulative time of development ( $y$, days) of the first nine larval stages $(x)$ of Macrobrachium vollenhovenii reared individually in different salinities. Only data from larvae surviving during the entire experiment are included. Regression equations computed from all data (number of observations, $n$ ), but only mean values plotted in graphs.

Table 8. - Mean. minimum. and maximum development (duration in days) of Macrobrachium vollenhovenii larvae to reach stage IX in different salinities ( $\bar{x} \pm S D$; number of individuals. $n$ ). Significance: comparison of mean durations in two subsequent salinity steps ( $t$ tests, n.s. $=$ not significant, ${ }^{*} p<0.05,{ }^{* *} p<0.01,{ }^{* * *} p<0.001$ ).

\begin{tabular}{|c|c|c|c|c|c|c|}
\hline \multirow{2}{*}{$\begin{array}{c}\text { Salinity } \\
\left(\% \%_{00}\right)\end{array}$} & \multirow{2}{*}{$n$} & \multirow{2}{*}{$\begin{array}{c}\text { Mean } \\
\text { duration }\end{array}$} & \multirow{2}{*}{$\pm \mathrm{SD}$} & \multicolumn{2}{|c|}{ Days } & \multirow{2}{*}{$\begin{array}{l}\text { Signi- } \\
\text { ficance }\end{array}$} \\
\hline & & & & Min & Max & \\
\hline \multicolumn{7}{|c|}{ Series I } \\
\hline 8 & 17 & 23.53 & 2.60 & 19 & 28 & - \\
\hline 10 & 21 & 23.00 & 2.68 & 19 & 27 & n.s. \\
\hline 12 & 33 & 20.33 & 1.95 & 18 & 26 & $* * *$ \\
\hline 14 & 44 & 19.93 & 2.39 & 17 & 29 & n.s. \\
\hline 16 & 41 & 19.05 & 1.55 & 17 & 23 & * \\
\hline \multicolumn{7}{|c|}{ Series II } \\
\hline 12 & 33 & 21.67 & 1.99 & 18 & 26 & - \\
\hline 16 & 38 & 19.87 & 1.76 & 17 & 24 & *** \\
\hline 20 & 35 & 19.06 & 1.73 & 17 & 25 & n.s. \\
\hline 24 & 43 & 19.12 & 1.79 & 17 & 23 & n.s. \\
\hline 28 & 35 & 19.57 & 1.88 & 17 & 23 & n.s. \\
\hline
\end{tabular}
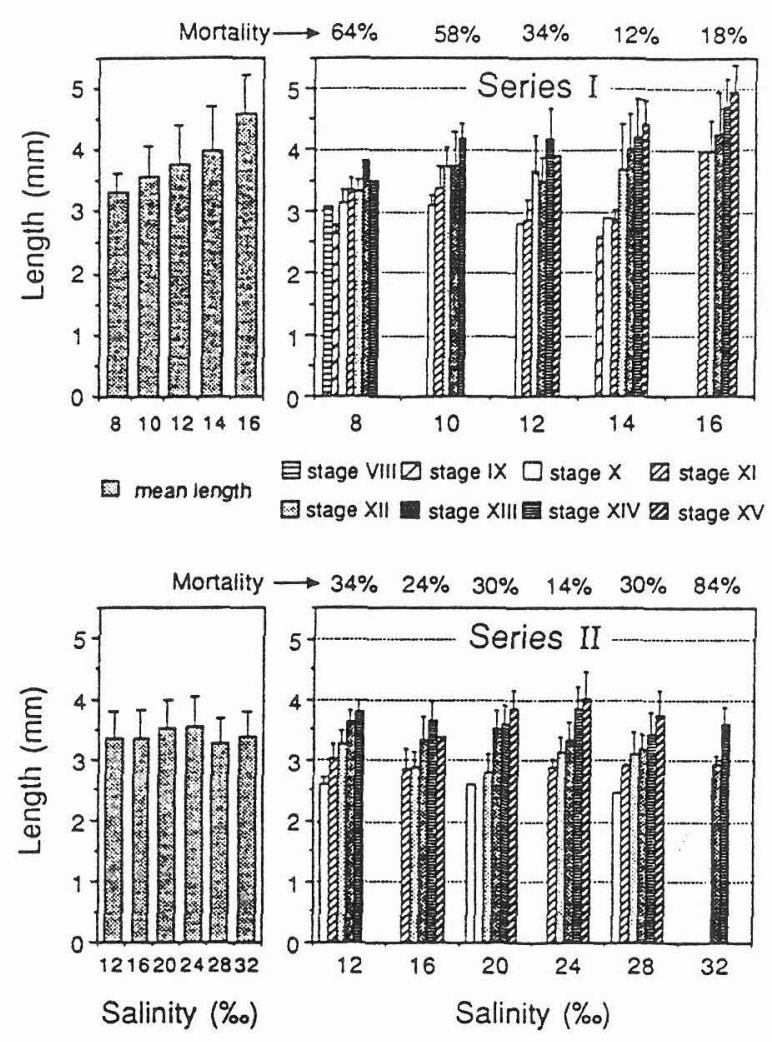

Figure 14. - Final lengths $(\bar{x} \pm S D)$ and mortality in Macrobrac/tium zollenhovenii larvae after 30 davs of individual rearing in different salinities. Left side: lengths of combined larval stages; right side: lengths per stage.

series most animals were found in the same stage (XIII). The few survivors at $32 \%$ also reached stages XIII and XIV. Although mean initial size differed significantly ( $t$-test, $p<0.001$ ) between the two series (series I with $\bar{x}=1.617 \pm 0.025 \mathrm{~mm}$, series II with $\bar{x}=1.509 \pm 0.038 \mathrm{~mm}$ ) and larvae in series II performed a reduced growth, similar trends were observed in mean daily growth rates during the 30 days. At $16 \%$, the daily growth rate reached $0.095 \mathrm{~mm} /$ day, whereas at $8,10,12$ and $14 \%$ it was only 0.05 , $0.06,0.07$ and $0.075 \mathrm{~mm} / \mathrm{day}$, respectively. In the second series, $0.06 \mathrm{~mm} /$ day was observed at 12 and $16 \%, 0.07$ at $24 \%$ (the apparent optimum in this series) and $0.057 \mathrm{~mm} /$ day at $28 \%$.

Comparing growth in individually kept larvae with that in mass culture (both at $12 \%$, for a period of 30 days after hatching) no significant differences were found ( $t$-test, $p=0.266$, table 10 ), although mass-cultured larvae showed slightly higher mean, maximum, and minimum lengths.

\section{Postlarvae (PL)}

The growth of postlarvae in terms of length and weight was traced for 12 weeks (fig. 15). During this period their mean length doubled and their mean fresh weight increased by a factor of 12 . The juveniles 
Table 9. - Length $(\bar{x} \pm S D)$, number of survivors $(n)$, and stage frequency in Macrobrachium zollenhozenii larvae after 30 days of rearing in different salinities (2 series)

\begin{tabular}{|c|c|c|c|c|c|c|c|c|c|c|c|}
\hline \multirow{2}{*}{$\begin{array}{c}\text { Salinity } \\
(\% / 00)\end{array}$} & \multirow{2}{*}{$n$} & \multirow{2}{*}{$\begin{array}{l}\text { Mean } \\
\text { length } \\
(\mathrm{mm})\end{array}$} & \multirow{2}{*}{$\begin{array}{l} \pm S D \\
(\mathrm{~mm})\end{array}$} & \multicolumn{8}{|c|}{ Frequency of stages $(\%)$} \\
\hline & & & & VIII & IX & $\mathrm{X}$ & XI & XII & XIII & XIV & $X V$ \\
\hline \multicolumn{12}{|c|}{ Series I } \\
\hline 8 & 18 & 3.22 & 0.33 & 5.6 & 11.1 & 22.2 & 27.8 & 22.2 & 5.6 & 5.6 & 0 \\
\hline 10 & 21 & 3.50 & 0.47 & 0 & 0 & 28.6 & 28.6 & 9.5 & 23.8 & 9.5 & 0 \\
\hline 12 & 33 & 3.69 & 0.61 & 0 & 0 & 3.0 & 9.1 & 12.1 & 36.4 & 36.4 & 3.0 \\
\hline 14 & 44 & 3.86 & 0.73 & 0 & 4.5 & 2.3 & 4.5 & 25.0 & 31.8 & 22.7 & 9.1 \\
\hline 16 & 41 & 4.48 & 0.61 & 0 & 0 & 0 & 2.4 & 17.1 & 24.4 & 41.5 & 14.6 \\
\hline \multicolumn{12}{|c|}{ Series II } \\
\hline 12 & 33 & 3.31 & 0.42 & 0 & 0 & 12.1 & 18.2 & 30.3 & 12.2 & 18.2 & 0 \\
\hline 16 & 38 & 3.31 & 0.44 & 0 & 0 & 0 & 10.5 & 15.8 & 39.5 & 31.6 & 2.6 \\
\hline 20 & 35 & 3.46 & 0.49 & 0 & 0 & 2.9 & 0 & 17.1 & 34.3 & 20.0 & 25.7 \\
\hline 24 & 43 & 3.50 & 0.48 & 0 & 0 & 0 & 11.6 & 9.3 & 39.5 & 23.3 & 16.3 \\
\hline 28 & 35 & 3.24 & 0.38 & 0 & 0 & 2.9 & 11.4 & 17.1 & 31.4 & 28.6 & 8.6 \\
\hline 32 & 8 & 3.35 & 0.41 & 0 & 0 & 0 & 0 & 0 & 37.5 & 62.5 & 0 \\
\hline
\end{tabular}

Table 10. - Mean length of Macrobrachium vollenhovenii larvae reared individually and in mass culture $012 \%$, lengths in mm. $n$ : number of observations).

\begin{tabular}{lcc}
\hline & $\begin{array}{c}\text { Individual } \\
\text { culture }\end{array}$ & Mass culture \\
\hline Minimum & 2.66 & 3.05 \\
Maximum & 4.83 & 4.86 \\
Mean $(\bar{x})$ & 3.69 & 3.84 \\
$\pm S D$ & 0.61 & 0.42 \\
$n$ & 33 & 30 \\
$t$-test & \multicolumn{2}{c}{1.1225} \\
\hline
\end{tabular}

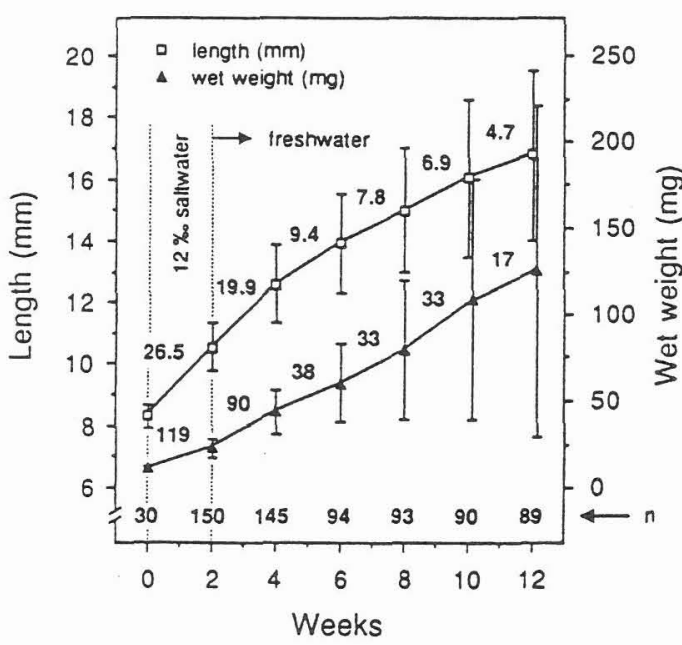

Figure 15. - Postlarvae growth of Macrobrachium rollenhorenii (length, wet weight) during the first 12 weeks after metamorphosis. $n=$ number of observations. Interval numbers = gain per fortnight $(\%)$.

grew to a maximum length of $31 \mathrm{~mm}$ and to a weight of $0.8 \mathrm{~g}$.

Vol. 6. $n^{\circ} 2 \cdot 1993$
The shelters provided effectively prevented cannibalism. Only five of the initial $150 \mathrm{PL}$ died during the first four weeks. An accidental loss of 51 animals occurred in the fifth week due to a clogged drain which caused an overflow. Another five individuals of the remaining 94 died by the twelfth week.

In figure 16 the general relationship of total length and fresh weight is presented. The mean percentage gain per fortnight decreased with time in both length and weight (fig. 15). While the mean absolute length gain continuously declined from 2.2 to $0.76 \mathrm{~mm}$ per fortnight, the maximum gain decreased only until the 6 th week, then increased to $4 \mathrm{~mm}$ per fortnight. This high growth rate remained constant until the end of the observation. Therefore, the different size groups with different growth rates are formed during later development.

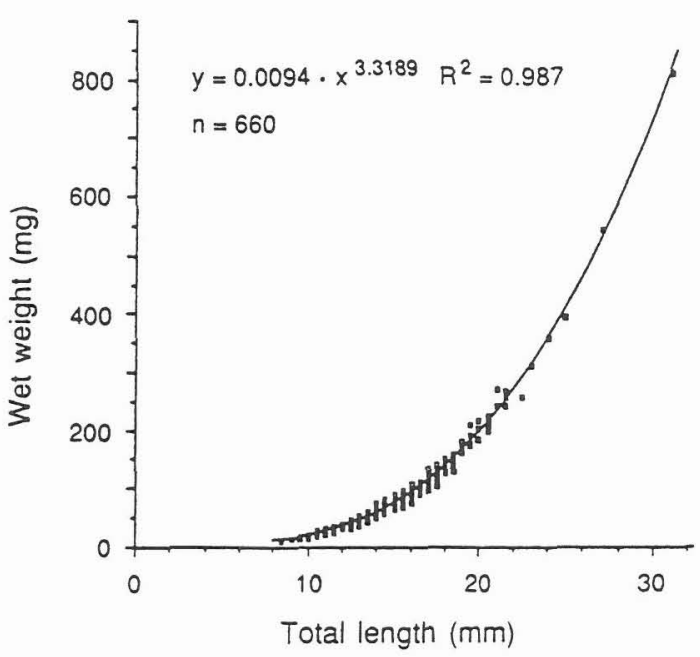

Figure 16. - Relationship between total length and live wet weight of Macrohrachium iollenhoìchii postlarvae. 


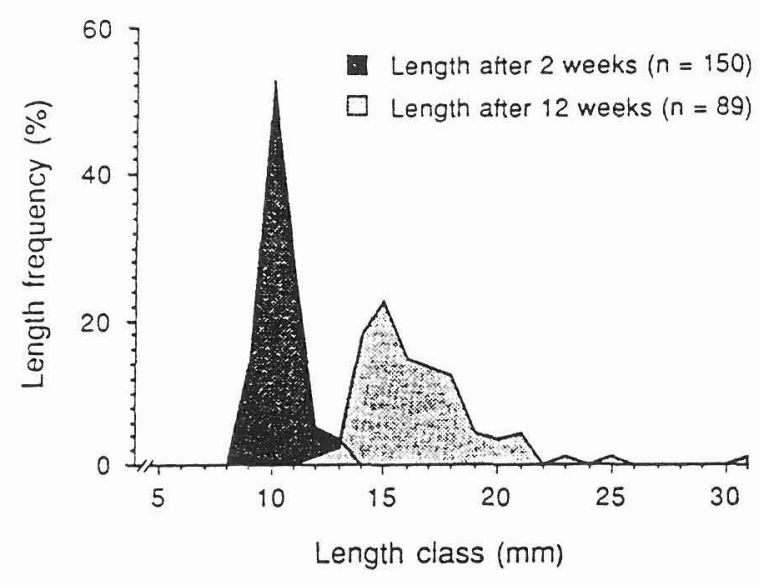

Figure 17. - Length frequency distribution of Macrobrachitum zollenhozenii postlarvae, 2 and 12 weeks after metamorphosis.

As a consequence, a comparison of length frequencies observed after two and after 12 weeks (fig. 17) shows a highly increased size range. The size-frequency distribution was unimodal with 6 one-mmclasses after two weeks, but 13 classes after 12 weeks. The latter contained many small animals, fewer medium-sized, and a few very large individuals.

As the culture of these prawns was continued in another experiment, it was possible to record the first occurrence of an ovigerous female from this brood. found 17 weeks after metamorphosis, with $49 \mathrm{~mm}$ length and $3.8 \mathrm{~g}$ fresh weight.

\section{DISCUSSION}

\section{Successful rearing}

Possible alternatives to $M$. rosenbergii as culturable freshwater prawns were assumed to exist in tropical Africa by the "Second Macrobrachium Workshop" in 1976. Rabanal (1982) listed Macrobrachizum vollenhoienii under the heading "culture planned", but cultivation projects with this species were unsuccessful (Powell, 1983).

In our experiments, laboratory rearing of Macrobrachium iollenhoienii succeeded for the first time from hatching through metamorphosis, and to sexual maturity in a mass culture system that had already proven successful for the rearing of $M$. rosenbergii. In addition, survival, growth and development data are reported for larvae reared individually in different salinities. Although no statistically significant differences could be shown between the mass cultured larvae and those kept individually, the flow-through culture technique provided larvae in much better biological condition than those individually reared. Two reasons might be considered here for this result: the smaller ones are being fed in the mass culture-not possible with individually kept larvae: or, due to their swarming behaviour, larvae kept in mass culture grow better.

The salinity chosen initially for mass culture $(12 \%, 00)$ was in the tolerated range for the larvae of this species, but later experiments revealed an optimal salinity range of $16-24 \% / 00$. This study showed that pure freshwater does not permit development of Macrobrachium zollenhovenii larvae. This is in contrast to statements by Prah (1982), who characterized it in Ghana as a pure freshwater species, completing its life cycle in riverine and lacustrine habitats with salinities from 0.005 to $0.012 \%$.

The economic feasibility of mass-rearing Macrobrachium rollenhorenii larvae was questioned by Powell (1983). He suggested using mass migrations of juveniles as a cheap and reliable source of seed stock for aquaculture purposes. Although this should also be considered, commercial aquaculture cannot rely exclusively on such seasonal events.

From reviews of methodology, potential, and problems of $M$. rosenbergii culture (Ling, $1967 a, b$; Fujimura, 1966, 1970, 1974; Shang, 1972) it is obvious that the most difficult task is the "provision of seedlings". Our results demonstrate that Macrobrachium iollenhovenii larvae can be reared successfully, if methods given by the authors cited above for the rearing of Macrobrachium rosenbergii larvae are adopted and employed in conjunction with the information given in this report.

\section{Evaluation of adaequacy of experiments}

Hartnoll and Dalley (1981) formulated four prerequisites for the laboratory valid investigation of crustacean growth:

- each experiment must use offspring from a single brood,

- numbers of larvae have to be adequate,

- environmental conditions have to be kept constant and closely controlled,

- the observation time of the sequence of instars has to be long enough.

Costlow et al. (1960) also reported differences in viability of larvae obtained from different females. They also found in a survey on decapod larval development that the best results were usually obtained when zoea larvae were reared in salinities similar to those in which the eggs hatched. They consequently took separate females for each salinity experiment. In addition, Scheltema and Williams (1982) observed a considerable variation in larval survival among different broods of a single female with apparently no differences in culture conditions. Even different batches of larvae of one female showed different responses to various stress conditions. Reeve (1969) also suggested that different broods of Palaemon serratus showed different responses to the same salinity and even grew differently at the same temperature. 
No combined temperature-salinity trials could be conducted in our first study. Salinity was considered as an "ecological master factor" (Kinne, 1963), since West African estuaries are characterized by uniform high temperature conditions, but by strong salinity fluctuations depending on heavy seasonal rainfalls. We attempted to keep the temperature constant during our experiments.

Even in our temperature-controlled room, gradients of $0.6-1.3^{\circ} \mathrm{C}$ were observed. Prior to water exchange the salinities were again checked and temperated to the daily mean water temperature determined for each salinity series, to minimize temperature differences to $\pm 0.2^{\circ} \mathrm{C}$ before and after water exchange. This precision in temperature was thought necessary first of all due to New and Singholka (1982) who reported that sudden changes of water temperature, even as small as $1^{\circ} \mathrm{C}$, could cause shock and mortality to larvae. Secondly, to determine the effect of salinity alone, concerted efforts were made to control all other variables and therefore minimize the variation in test results. The daily water exchange required about 4.5 hours.

Artefacts due to laboratory rearing have also to be kept in mind. However, a first ovigerous female in the grow-out trial measured about the same size $(49 \mathrm{~mm})$ as the smallest ripe female reported by Udo and Ekpe (1991) from catches in the Cross River $(54 \mathrm{~mm})$.

Considering possible artefacts together with the labor-intensive and time-consuming process, and taking into account that variability among culture containers could make it difficult to identify optima precisely, Cooper and Heinen (1991) questioned this generally adapted method of optimal salinity determination by culturing larvae at different salinities. Instead, they recommended a starvation test to determine optimal salinities for larval $M$. rosenbergii, resting on their argumentation that, at optimal salinities, larvae should expend the least amount of energy on osmoregulation and that starved larvae should live longest at these salinities. The marked deficiency of such a test is the only validity for first and second stage larvae, thus presupposing a constant salinity requirement throughout the full larval life. This assumption is disproved by our findings of a stagespecific salinity requirement, in line with the discussion of variability in the number and duration of moults given below.

Last, but not least, the taxonomic identity must be checked; Prah's (1982) findings of the pure freshwater nature of Macrobrachium vollenhovenii may point to different races or even species. The same possibility of two distinct physiological races was suggested for M. amazonicum by Zanders and Rodriguez (1992), who observed this species inhabiting both freshwater and high saline waters of up to $36 \%$. Erroneous records of the Malayan Riceland Prawn, $M$. lanchesteri from India were just recently corrected
(Jalihal, 1992) as actually belonging to three different species, viz. M. unikarnatakae. M. tivarii and $M$. kistnensis, revealing that $M$. lanchesteri is not found in India, and that all earlier records from India are erroneous.

\section{Egg incubation}

The range of development time in Macrobrachium vollenhovenii eggs was $13-16$ days at $28.3^{\circ} \mathrm{C}$, where the females were gradually exposed to increasing salinities from freshwater to $12 \%$. This egg incubation time is about five days shorter than in $M$. rosenbergii (New and Singholka, 1982) and shorter than in all other Macrobrachium species listed in table 11 , except for $M$. carcinus, for which Choudhury $(1971$ a) reported a 10-13 days incubation time, and $M$. amazonicum for which Guest (1979) could demonstrate a shorter incubation time at higher temperatures.

New and Singholka (1982) reported rather weakly on the procedures of egg hatching for $M$. rosenbergii, but recommended using brackish water. Ching and Velez (1985) demonstrated that salinity had no effect on the incubation period of $M$. heterochirus. In the present study, we adapted the females in the two salinity trials to 12 and $20 \%$ respectively, i.e. to the mean salinity of each experiment.

In several marine crustaceans, the number of eggs was found a linear function of the length of the female (Shakuntala, 1977). This was demonstrated also for Macrobrachium species, for instance, $M$. idae (Katre and Pandian, 1972), M. lamarrei (Shakuntala, 1977), M. amazonicum (Rojas and Silva, 1979; Guest, 1979), M. nobilii (Pandian and Balasundaram, 1982) and M. ohione (Truesdale and Mermilliod. 1979). In addition to $M$. rosenbergii's fecundity data given in table 11, egg numbers of 1,200 to 90.000 are recently reported (Kok Jee and Kok, 1991) for individuals measuring 9.0 to $15.8 \mathrm{~cm}$ total length. In Macrobrachium vollenhovenii caught in the Cross River estuary, Udo and Ekpe (1991) suggested an exponential relationship between fecundity and length.

\section{Survival}

Survival rates of developing eggs of most decapod crustaceans are, in nature, less than $0.1 \%$ (Bagenal, 1967). Larval mortality also varies with previous temperature and salinity history (Lucas, 1972; Rosenberg and Costlow, 1979), or with the amount of food available during critical periods (Anger et al., 1981). Preston (1985) suggested that the ability to adapt to environmental conditions is fixed during early stages of development, in line with Kinne (1964) who proposed that non-genetic embryonic adaptation to salinity may be attributed to irreversible conditioning by the spawning medium. In our experiments. the successful 
Table 11. - Larviculture details of various Macrobrachium species: Incubation period. temperature. salinity and fecundity in relation to female size: different methods of size measurement indicated. For some rearing salinities only qualitative classifications such as brackish. fresh or lake water are reported instead of a measured salinity.

\begin{tabular}{|c|c|c|c|c|c|c|c|}
\hline Species & $\begin{array}{l}\text { Incubation } \\
\text { period (hatch. } \\
\text { after } x \text { days) }\end{array}$ & $\begin{array}{c}\text { Larvae } \\
\text { culture } \\
\text { salinity }(\% / 00) \\
\end{array}$ & $\begin{array}{c}\text { Temperature } \\
{ }^{\circ} \mathrm{C} \\
\end{array}$ & $\begin{array}{l}\text { Gravid } \\
\text { female } \\
\text { size }(\mathrm{cm})\end{array}$ & Method & $\begin{array}{c}\text { Number } \\
\text { of } \\
\text { eggs }\end{array}$ & Source \\
\hline M. acanthurus & $16-18$ & $\begin{array}{l}15-20 \\
16-18\end{array}$ & $\begin{array}{c}23-27 \\
30\end{array}$ & & & & $\begin{array}{l}\text { Choudhury } 1970,1971 \text { c } \\
\text { Dobkin et al. } 1974\end{array}$ \\
\hline M. amazonicum & $19-24$ & 10 & $24 \pm 2$ & $5-11$ & $r$ & $195-2200$ & Guest, 1979 \\
\hline M. amazonicum & $12-15$ & 10 & $30 \pm 1$ & & & & Guest. 1979 \\
\hline M. amazonicum & $15-20$ & 0 & 26 & $4.1-7.2$ & $r$ & 953 & Romero, 1982 \\
\hline M. amazonicum & $n$ & $7-28$ & 25 & & & & McNamara et al., 1983 \\
\hline M. americanum & & & & 18.7 & $r$ & 228000 & Diaz, 1973. Smitherman et al., 1974 \\
\hline M. americanum & & 10 & 28 & & & & Arana, 1974 \\
\hline M. americanum & & & $25.5-27.9$ & $14.9-15.6$ & $r$ & $86000-87000$ & Smitherman et al., 1974 \\
\hline M. americanum & 15 & 15 & $29.5 \pm 0.5$ & 12.5 & $b$ & 80000 & Monaco, 1975 \\
\hline M. australiense & $n$ & & $21-28$ & $0.8-1.2$ & $c$ & $97-197$ & Fielder, 1970 \\
\hline M. australiense & $41-42$ & freshwater ${ }^{\circ}$ & $19-23$ & & & 200 & Ruello et al., 1973 \\
\hline M. australiense & & 0.15 & 25,30 & & & & Lee and Fielder. 1981/1982 \\
\hline M. carcinus & $10-13$ & $14-17.5$ & $24-28$ & & & & Choudhury, $1971 a .1971 b$ \\
\hline M. carcinus & & 15 & $26-31$ & & & 70000 & Dobkin et al., 1974 \\
\hline M. heterochirus & $14-19$ & $0,10,17.5^{*}$ & $26-28$ & $1.8-6.1$ & $l$ & $184-5031$ & Ching and Velez. 1985 \\
\hline M. holthuisi & $n$ & 14 & $20-25$ & & & & Moreira et al.. 1979 \\
\hline M. idae & about 15 & freshwater & $25 \pm 2$ & $4.3-4.9$ & $r$ & $12-76$ & Pandian and Katre, 1972 \\
\hline M. iamarrei & $n$ & freshwater & $25 \pm 2$ & $4.1-5.3$ & $r$ & $20-158$ & Shakuntala, 1977 \\
\hline M. lanceifrons & 22 & lake water & $25-28$ & $3.0-5.5$ & $r$ & $180-780$ & Rasalan el al.. 1969 \\
\hline M. lanchesteri & & freshwater & & 3.3 & $n$ & & Johnson. 1968 \\
\hline M. lar & $25-35$ & & & & & & Muranaka, 1977 \\
\hline M. malcolmsonii & & brackish & & & & & Pande. 1984 \\
\hline M. niphanae & $n$ & freshwater & $24.5-28$ & $2.3-3.4$ & $e$ & $32-81$ & Shokita et al.. 1991 \\
\hline M. nobilii & $12-19$ & freshwater & $27 \pm 2$ & $3.4-4.4$ & $n$ & $660-3300$ & Pandian and Balasundaram. 1982 \\
\hline M. noraehollandiae & & 23 & $13-28$ & $1.8-1.9$ & $c$ & $3742-3268$ & Greenwood el al.. 1976 \\
\hline M. olfersii & & $2 !$ & 30 & & & $150-200$ & Dugger and Dobkin, 1975 \\
\hline M. olfersii & & 14 & 20 & & & & McNamara el al. 1980 \\
\hline M. ohione & $n$ & & $12-28$ & $5.4-8.0$ & $r$ & $6293-24800$ & Truesdale and Mermilliod. 1979 \\
\hline M. rosenbergii & about 19 & $12-14$ & $26-28$ & 18 & $r$ & $60000-100000$ & $\begin{array}{l}\text { Ling and Merican, 1961; Ling, } \\
1969 a, b\end{array}$ \\
\hline M. rosenbergii & & $11.9-12.3$ & $28 \pm 0.5$ & & & & Uno and Kwon Chin Soo, 1969 \\
\hline M. rosenbergii & & $5-26$ & $28 \pm 1$ & & & & Wickins, $1972 b$ \\
\hline$M$. rosenbergii & & $15-17$ & $26.6-30$ & & & & Takata, 1974 \\
\hline M. rosenbergii & & $0-15$ & & & & & Perdue and Nakamura. 1976 \\
\hline M. rosenbergii & & $12-16$ & $28-30$ & & & & $\begin{array}{l}\text { Sandifer et al., 1977; Sandifer and } \\
\text { Smith, } 1985\end{array}$ \\
\hline$M$. rosenbergii & & 15 & $26-28$ & & & & Moller, 1978 \\
\hline M. rosenbergii & & $12-14$ & $27-29$ & & & & Stephenson and Knight, 1980 \\
\hline M. rosenbergii & $18-23$ & $12 \pm 2$ & $26-31$ & 10.12 & $r$ & $10000-30000$ & New and Singholka, 1982 \\
\hline M. rosenbergii & & $11-15$ & $28-30$ & & & & Malecha, 1983 \\
\hline M. rosenbergii & $16-26$ & $6.8-34$ & $28-31$ & & & & Gomez Diaz. $1987 a . b$ \\
\hline M. tenellum & & $0-15$ & $25-35$ & & & & Guzman et al.. 1977 \\
\hline M. vollenhovenii & & & & $7.6-11.3$ & $e$ & $12000-45000$ & Miller, 1971 \\
\hline M. iollenhovenii & & 0 & & $8.0-16.7$ & $n$ & $7000-38000$ & Prah, 1971, 1982 \\
\hline M. vollenhovenii & & & & $5.4-13.5$ & $r$ & $1160-170570$ & Udo and Ekpe, 1991 \\
\hline
\end{tabular}

* Salinity had no effect on the incubation period of $M$. heterochirus.

Method: $r=$ total length $=$ tip of rostrum to end of telson; $c=$ carapace length; $e=$ base of eye-stalk to tip of telson; $b=$ total length $=$ base of rostrum to end of telson; $l=$ last rostral tooth to tip of the telson; $n=$ not reported.

completion of the life history of Macrobrachium vollenhorenii could be shown to depend largely on survival in the first four zoeal stages, which stresses the particular importance of knowing and meeting their specific environmental requirements in cultivation of this species.
In our mass culture, about $12 \%$ of the initially stocked 4.500 larvae settled as postlarvae, in spite of a suboptimal salinity (see above). Dobkin et al. (1974) yielded a maximum survival rate of $21 \%$ for $M$. acanthurus and $2.5 \%$ for $M$. carcinus in larviculture. Wickins (1972b) managed to get a $27 \%$ survival 
Table 12. - Survey of the number of larval stages reported for various . Macrobrachum species.

\begin{tabular}{|c|c|c|c|c|}
\hline Species & $\begin{array}{c}\text { Number } \\
\text { of } \\
\text { larval stages }\end{array}$ & $\begin{array}{l}\text { Rearing } \\
\text { salinity } \\
(\% / 00)\end{array}$ & Remarks & Source \\
\hline M. acanthurus & 10 & $15-20$ & $11-12$ moults & Choudhury, 1970 \\
\hline M. acanthurus & * & $16-18$ & $18-23$ moults & Dobkin, 1971 \\
\hline M. amazonicum & $8-9$ & 10 & & Guest, 1979 \\
\hline M. americanum & 11 & 15 & Optimum salinity may be different & Monaco, 1975 \\
\hline M. australiense & 3 & fresh & & Fielder, 1970 \\
\hline M. australiense & 3 & $0-15$ & & Lee and Fielder, $1981 / 1982$ \\
\hline M. carcinus & 5 & $\sim 20$ & $\begin{array}{l}\text { Convenient stages chosen to illustrate } \\
\text { morphological changes. They do not } \\
\text { represent moult stages }\end{array}$ & Lewis and Ward. 1965 \\
\hline M. carcinus & 12 & & Intermediate stages can occur & Choudhury, 1971 a \\
\hline M. lamarrei & 3 & fresh & & Rajyalakshmi, 1961 \\
\hline M. niphanae & $2+1$ & fresh & 2 zoeal, 1 megalopal and 2 juvenile stages & Shokita et al., 1991 \\
\hline M. noiaehollandiae & 10 & 23 & $\begin{array}{l}10 \text { morphologically distinct zoeal stages } \\
\text { correspond to } 10-15 \text { moults }\end{array}$ & Greenwood el al.. 1976 \\
\hline M. rosenbergii & 13,11 & $12-14$ & $\begin{array}{c}\text { Stage I-V: each moult yields } \\
\text { a new morphol. stage } \\
\text { Stage VI-XI: mainly two moults } \\
\text { between stages, en total } 15 \text { moults }\end{array}$ & Ling, $1969 a: 1969 b$ \\
\hline M. rosenbergii & 11 & $11.9-12.3$ & & Uno and Kwon Chin Soo, 1969 \\
\hline M. rosenbergii & 17 & 13.6 & & Gomez Diaz and Kasahara, 1987 \\
\hline
\end{tabular}

* Dobkin 1971, suggested that selection of the number of morphological stages is a somewhat arbitrary process

rate of $48,000 M$. rosenbergii to postlarvae, and Fujimura and Okamoto (1970) reared $21 \%$ of $1,000,000$ larvae to the PL-stage. Our result of a $12 \%$ yield attained at a salinity of $12 \%$ has to be related to our salinity trials which showed higher survival rates at 14 to $28 \%$, thus indicating sub-optimal salinity conditions for the mass culture and also pointing to a higher salinity demand in this species' development than in that of $M$. rosenbergii, for which a $12 \%$ salinity is generally adopted since New and Singholka (1982).

\section{Moults and stages}

To our knowledge, there is no detailed morphological description of Macrobrachium vollenhovenii larvae: this will be given in a later paper. The term "larval stages" as used in this report has to be considered as preliminary for moults occurring after stage VII. The first seven moults could easily be traced because they yielded distinct zoeal stages. Another eight larval instars are suggested by daily growth increment analysis. Therefore a total of 14 zoea-larval stages is assumed, followed by a postlarval stage.

Dobkin (1971) suggested that the definition of morphological stages can be a somewhat arbitrary process, as morphologically intermediate stages may occur. In fact, the number of observed "stages" varies considerably in Macrobrachium species, as shown in table 12 for $M$. rosenbergii. Whereas Uno and Kwon Chin Soo (1969) defined just 11 stages in comparison to 13 stages described by Ling (1969 b), a more recent

Vol. 6. $n^{\circ} 2-1993$ report by Gomez Diaz and Kasahara (1987) identified 17 morphologically distinct larval stages. In addition, variability in larval development due to rearing conditions is well documented (Broad, 1957; Costlow, 1965).

Our results indicate a stage-specific response of the Macrobrachium vollenhovenii larvae. Higher salinities appeared to shorten the Intermoult period (IP) in early stages, but to extend the IP in later stages. Thus, the duration of the individual stages and the over-all time required for larval development are affected by salinity conditions. In Macrobrachitum spp. Choudhury (1971) also reported shorter IP at higher salinities for $M$. carcinus, but this coincided with an increased mortality.

A high degree of variation in the larval development is stated as "normal" in shrimp and prawns by Criales and Anger (1986) in their studies of the larval developments of two Crangon spp. A review on influences of various environmental factors on the number of premetamorphic moults is given by Knowlton (1974). Rochanaburanon and Williamson (1976) suggested that larval development of Crangon crangon, unlike that of other caridean species, may be uninfluenced by environmental factors, whereas Criales (1985) found considerable morphological variation both in laboratory cultures and in field samples. This variability is widely observed in decapod crustaceans and reviewed by Christiansen and Anger (1990). especially for brachyuran and anomuran species. The variability in larval development might be influenced 
by genetic factors (with hatches from different individuals. also observed under constant conditions by Montu et al.. 1990) or by environmental variables such as temperature and salinity. In addition. food has to be considered. as Broad (1957) reported varying numbers of stages for Palaemonetes pugio and P. zulgaris according to diet. Templeman (1936) already found that a reduction in food produced longer IP and sometimes produced an "extra" larval stage. In contrast. Costlow et al. (1960) never observed that variations in temperature and salinity could alter the number of stages of Sesarma cinereum. pointing to species-specific requirements. surpassed by further larval stage-specific requirements as demonstrated in our experiments. Williamson (1982) concluded. however, that the minimal number of moults should occur under optimal conditions for survival. Besides these generally cited types of stress, social factors in Macrobrachium might already influence variability in larval development, only visible in mass reared larvae due to the marked intraspecific interactions causing variations in growth (Raanan et al.. 1991: Barki. 1989. $1991 a, b)$, and resulting in adults as three distinct morphotypes which differ in their morphology. physiology and behaviour

In nature. no constant salinity conditions exist: therefore our laboratory results have to be compared with field observations. Larvae might response to salinity stress in nature with such different compensatory devices as escape. contact reduction, regulation or adaptation (Kinne. 1966).

Dobkin (1969) primarily recommended using those Macrobrachium species for aquaculture that undergo abbreviated or direct development, in order to lower costs of larval rearing.

Some information is available on the salinity tolerance of adult and juvenile Macrobrachium, but there is little on that of larval stages. Sollaud (1923; cf. Fielder, 1970) distinguished three basic types of larval development in the Palaemonidae:

- marine and brackish water species producing many small eggs which develop through numerous larval stages,

- freshwater species producing fewer, but larger eggs. with abbreviated larval development of usually three stäges.

- freshwater species with direct development. hatching as postlarvae.

Studies on effects of salinity on the larval development of Macrobrachium sp. larvae reared in the laboratory are limited. Lewis and Ward (1965) as well as Choudhury $(1971 b$ ) found in $M$. carcinus that "all larvae reared in freshwater died at stage I without moulting." indicating that this species belongs to the first of Sollaud's categories. The same is true for other Macrohrachium species where exposure to higher salinity decreased for the duration of moult cycles. e.g. M. acanthurus (Choudhury. 1971 a. h:
Dobkin. 1971). M. holthuisi (Moreira el ul.. 1979) and M. olfersii (McNamara et al.. 1982). M. potiuna is said to be entirely independent of saline water for development (McNamara et al.. 1991).

The response of larval IP to salinity variations is not yet clear. Structures responsible for neurohormonal regulation of the moulting cycle are located at the eye-stalk (Passano, 1960: Silverthorn. 1975a. b. McNamara et al.. 1980. Charmantier et al.. 1988). During the ontogenesis of the eyestalk the structures and locations of these organs. especially of the larval sensory pore and of the organ of Bellonci. undergo considerable changes and movements between larval stages: consequently, metabolism and behaviour are also implied as differing (Bellon-Humbert et al.. 1978). Besides this optic ganglia. the ion uptake and excretory mechanisms are controlled by the esophageal and thoracic ganglion and the pericardial organs (McNamara et al.. 1991).

Most Macrobrachium species are catadromous species. while $M$. australiensis (Ruello et al., 1973). $M$. potiuna (Müller, 1892). M. iheringi and $M$. borelli have lost the dependence on brackish water for reproduction. Lee and Fielder (1981/1982) demonstrated the ability of $M$. australiense larvae to complete metamorphosis in media ranging from freshwater to $15 \%$, with no difference in survival. For Macrohrachium rollenhovenii larvae. however. our results clearly indicated that the most suitable salinity conditions were between 16-28\% in terms of overall development times. whereas both lower and higher salinities showed adverse effects.

Stephenson and Knight (1980) reviewed the occurrence of $M$. rosenbergii in rivers. estuaries and backwaters in India, Pakistan. and Malaysia. where hatching and development takes place at salinities of 5$20 \%$. Perdue and Nakamura (1976) showed that growth of juveniles was greatest in animals kept in freshwater and waters of $2^{0}$. 00 . They also suggested that the isoosmotic point may change with age and size. Sandifer et al. (1975) demonstrated that $M$. rosenbergii $\mathrm{PL}$ are capable of both hyperosmotic and hypoosmotic regulation over a broad salinity range $\left(0-25^{\circ} / 00\right)$. Singh (1977) found that the adults hyperregulate between $0-17^{\circ}$,oo: above this salinity regulation ceased. Harrison and Lutz (1980) pointed out that newly metamorphosed PL are not fully able to regulate in $0^{\circ} / 00$. but develop this ability within one week. Pande (1984) observed $M$. rosenbergii PL in situ crawling up the river. where salinity ranged from 1 to $15^{\circ} \%$.

\section{Growth}

Laboratory studies of other decapods have shown that larvale attained a maximum size at the same temperatures that were optimum for survival (Rothlisberg. 1979: Johns. 1981). The same may be true for salinity. Macrohrachium iollenhorenii showed best 
growth performance between $16-24^{(1)} / 00$. with maximum average daily growth rates at $16^{\circ}$.00 (0.095 $\mathrm{mm} / \mathrm{d})$.

An adaptive response as proposed by Kinne (1963) was not observed in growth. If occurring. best growth would be expected at 12 and $20 \%$. at which the females were kept during the incubation time in the two salinity series. respectively. However, in the first trial, larvae grew fastest at 14 and $16 \%$, i.e. the highest salinities. and in the second series at $24 \%$ oo.

As pre-moult and post-moult lengths could not be determined for the individually kept larvae. further measurements on larval growth are needed to distinguish the type of growth (Kurata, 1962) in different stages of development. Nevertheless, the results of the present laboratory experiments indicate that both very low and high salinities had a negative effect on growth.

Growth curves shouid not be used for extrapolating later size, as these curves yield poor correspondence of predicted and observed data. Growth within stages follows different patterns.

There are conflicting reports in the literature regarding the effects of salinity on growth of other Macrobrachium sp., especially larval growth. Silverthorn and Reese (1978) found that in $M$. rosenbergii there were no significant differences among growth rates of 5.8 and $14^{\circ} / 00$ at $27^{\circ} \mathrm{C}$.

\section{Postlarvae}

Sexual and morphotypic differentiation were not determined in this study. therefore length structure could not be ascertained in the larval population. Nevertheless. size homogeneity in the PL stage changed to a polimodal frequency curve after 12 weeks. which could be partitioned into three groups resem. bling the typical size and morphotypic composition of M. rosenbergii populations (Fujimura and Okamoto. 1970: Cohen el al., 1981: Raanan el al.. 1991). In contrast. sexual dimorphism in size is pronounced in $M$. ohione: females grow to a larger size than do males (Truesdale and Mermilliod, 1979).

Our laboratory results should be checked by in silu observations and salinity measurements. In particular. behavioral responses should be studied. Hughes and Richard (1973) reported that female M. acunthurus bearing eggs are rheotactic, thus reaching saline waters as the suitable medium for the developmeni of larvae. They could also show that the vertical migration of larvae is an adaequate behavioural mechanism against offshore dispersion: larvae drop to the substrate when the salinity of the water decreases due to the beginning ebb tide. and thus avoid being displaced offshore by the faster-moving surface waters. Such clues are also needed for the interpretation of our laboratory results on the larval development and salinity tolerance of Macrohrachium iollenhorenii.

\section{Acknowledgements}

We wish to thank R. Reyes for cultivating the adults of Macrobrachium iollenhoienii, for the provision of parental moult data as well as for data on the egg incubation times. Dr. M. Taege transported the adults from Nigeria to Hamburg. Thanks are also due to Dr. M. Karakiri for measuring the larvae at the end of the second experiment. In the advanced stages of manuscript preparation. Dr. K. Anger aided us in discussions concerning various items of general crustacean biology. and improved the final manuscript by giving it a critical reading. Also our thanks go to $\mathrm{Ms}$. C. Battenfeld for correcting the English. The GKSS is also acknowledged for sponsoring the stay of the third author in Germany.

\section{REFERENCES}

Anger K., R. R. Dawirs, V. Anger, J. W. Goy, J. D. Costlow. 1981. Starvation resistance in first zoea of brachyuran crabs in relation to temperature. J. Crust. Biol.. 1. $518-525$.

AQUACOP, 1977. Macrobrachium rosenbergii (de Man) culture in Polynesia: Progress in developing a mass intensive larval rearing technique in clear water. Proc. World Maricult. Soc.. 8. $311-326$.

Arana M. F., 1974. Experiences sobre el cultivo del langostino Macrobrachium americanum (Bate) en el noroeste de Mexico. Simposio FAO/Carpas sobre acuicultura en America Latina. 1-9.

Bagenal T. B.. 1967. A short review of fish productivity. In: The Biologicui basis of freshwater fish production.
S. D. Gerking ed.. Blackwell Scientific Publications. Oxford. 89-112.

Barki A.. 1989. The agonistic behaviour of the freshuater prawn Macrobrachium rosenhergii. M. Sc: thesis. Tel Aviv Univ. 113 p.

Barki A.. I. Karplus. M. Goren. 1991 a. The agonistic behaviour of the three male morphorypes of the freshwater praw'n Macrobrachium rosenbergii (Crustacea. Palaemonidae). Behariour. 116. 252-277.

Barki A.. I. Karplus. M. Goren. 1991 h. Morphotype related dominance hierarchies in males of Macrohrachium rosenhergii (Crustacea. Palaemonidae). Behariout. 117. 145160.

Bellon-Humbert Ch.. M. J. P. Thijssen. F. V. Herp. 1978. Development, location and relocation of sensory and neurosecretory sites in the eyestalks during the larval and 
postlarval life of Palaemon serratus (Pennant). J. mar biol. Ass. U.K.. 58. $851-868$.

Broad A. C.. 1957. The relationship between diet and larval development of Palaemonetes. Biol. Bull. mar. biol. Lab. Woods Hole. 112. 162-170.

Bulnheim H.-P.. 1983. Biologische Anstalt Helgoland: Neubau der Zentrale. GIT Fach-., 27, 405-414.

Charmantier G., M. Charmantier-Daures. N. Bouaricha, P. Thuet. D. E. Aiken, J.-P. Trilles, 1988. Ontogeny of osmoregulation and salinity tolerance in two decapod crustaceans: Homarus americanus and Penaeus japonicus. Biol. Bull. mar. biol. Lab., Woods Hole, 175. 102-110.

Ching C. A.. M. J. Velez Jr., 1985. Mating, incubation and embryo number in the freshwater prawn Macrobrachium heterochirus (Wiegmann, 1836) (Decapoda, Palaemonidae) under laboratory conditions. Crustaceana, 49, 4248.

Christiansen M. E., K. Anger. 1990. Complete larval development of Galathea intermedia Lilljeborg reared in laboratory culture (Anomura: Galatheidae). J. Crustacean Biol., 10. 87-111.

Choudhury P. C., 1970. Complete larval development of the palaemonid shrimp Macrobrachium acanthurus (Wiegmann, 1836), reared in the laboratory. Crustaceana. $18,113-132$.

Choudhury P. C., 1971 a. Complete larval development of the palaemonid shrimp Macrobrachium carcinus (L.) reared in the laboratory (Decapoda. Palaemonidae). Crustaceana, 20. $51-69$.

Choudhury P. C.. 1971 b. Responses of larval Macrobrachium carcinus ( $L$.) to variations in salinity and diet (Decapoda, Palaemonidae). Crustaceana, 20. 113-120.

Choudhury P. C., 1971 c. Laboratory rearing of larvae of the palaemonid shrimp Macrobrachium acanthurus (Wiegmann, 1836). Crustaceana, 21. 113-126.

Cohen D.. Z. Raanan, T. Brody, 1981. Population profile development and morphotypic differentiation in the giant freshwater prawn Macrobrachium rosenbergii (de Man). J. World Maricult. Soc., 12, 231-243.

Cooper II R. K., J. M. Heinen, 1991. A starvation test to determine optimal salinities for larval freshwater prawns, Macrobrachium rosenbergii. Comp. Biochem. Physiol., 100A, 537-542.

Costlow Jr. J. D.. C. G. Bookhout, R. J. Monroe, 1960. The effect of salinity and temperature on larval development of Sesarma cinereum (Bosc) reared in the laboratory. Biol. Bull., 118, 183-202.

Costlow J. D., 1965. Variability in larval stages of the blue crab, Callinectes sapidus (Rathbun). Biol. Bull. mar. biol. Lab., Woods Hole, 128, 58-66.

Costlow J. D.. C. G. Bookhout, R. J. Monroe, 1966. Studies on the larval development of the crab. Rhithropanopeus harrisii (Gould). 1. The effect of salinity and temperature on larval development. Physiol. Zool.. 39. 81100.

Criales M. M.. 1985. Untersuchungen zur Larvalentwicklung von Crungon crangon $\mathrm{L}$. and Crangon allmanni Kinahan (Decapoda, Natantia, Caridea). Diss. Univ. Kiel. 223 p.
Criales M. M.. K. Anger, 1986. Experimental studies on the larval development of the shrimps Crangon crangon and C. allmanni. Helgoländer Meeresunters.. 40, 241-265.

Denne L. B.. 1968. Some aspects of osmotic and ionic regulation in the prawns Macrobrachium anstraliense (Holthuis) and M. equidens (Dana). Comp. Biochem. P/ysiol.. 26. 17-30.

Dobkin S., 1969. Abbreviated larval development in caridean shrimps and its significance in the artificial culture of these animals. FAO Fish. Rep.. 57, 935-946.

Dobkin S.. 1971. A contribution to knowledge of the larval development of Macrobrachium acanthurus (Wiegmann. 1836) (Decapoda, Palaemonidae). Crustaceana. 21. 294297

Dobkin S., W. P. Azzinaro. J. v. Montfrans. 1974. Culture of Macrobrachium acanthurus and $M$. carcinus with notes on the selective breeding and hybridization of these shrimps. Proc. 5th Ann. Workshop World Mariculture Soc. 51-62.

Dugger D. M.. S. Dobkin. 1975. A contribution to knowledge of the larval development of Macrobrachium olfersii (Wiegmann, 1836) (Decapoda. Palaemonidae). Crustaceana, 29, 1-30.

Fielder D. R.. 1970. The larval development of Macrobrachium australiense Holthuis, 1950 (Decapoda. Palaemonidae), reared in the laboratory. Crustaceana. 18, 60-74.

Fujimura T.. 1966. Notes on the development of a practical mass culturing technique of the giant prawn Macrobiachium rosenbergii. Indo-Pac. Fish. Counc. Proc.. 12th session, Honolulu, Hawaii (IPFC C66/WP47), 3 p.

Fujimura T., 1970. The giant prawn. Aloha aina sp. Dept. Land Nat. Res. Hawaii, 1, 9-12.

Fujimura T., H. Okamoto. 1970. Notes on progress made in developing a mass culturing technique for Macrobrac/sium rosenbergii in Hawaii. Indo-Pac. Fish. Counc. Proc. 14th session, Bangkok. Thailand. Symp.. 53. 17 p.

Fujimura T., 1974. Development of a prawn culture industry in Hawaii. Job Completion Report: July 1. 1969 to June 30. 1972. U.S. Dept. Commerce. NOAA. NMFS. 21 p. + vii p. figures.

Gamba A. L., 1982. Macrobrachitum: its presence in estuaries of the northern Venezuelan coast (Decapoda. Palaemonidae). Carib. J. Sci., 18, 23-24. 135-136.

Gamba A. L., G. Rodriguez. 1987. Migratory behavior of postlarval white. Pencueus schmitti, and river shrimps. Macrobrachium olfersi and Macrobrachium acanthurus, in their zone of overlap in a tropical lagoon. Bull. Mar. Sci., 40. 454-463.

Gomez Diaz G., 1987 a. Influence of parental history on the larval development of Macrobrachium rosenhergii (de Man). Int. J. Invert. Reprod. Dei.. 12. 45-56.

Gomez Diaz G.. 1987 b. Effect of environmental embryonic temperature on larval development of Macrobrachilum rosenhergii (de Man). J. exp. mar. Biol. Ecol.. 114. 3947.

Gomez Diaz G.. S. Kasahara. 1987. The morphological development of Macrobrachium rosenhergii (de Man) larvae. J. Fac. Appl. Biol. Sci.. 26. 43-56. 
Gray C. A.. 1991 a. Temporal variability in the demography of the palaemonid prawn Macrobrachium internedium in two seagrasses. Mar. Ecol. Prng. Ser.. 75, 227.237.

Gray C. A., 1991 b. Demographic patterns of the palaemonid prawn Macrobrachium intermedium in southeastern Australia: spatial hetcrogeneity and the effects of species of seagrass. Mar. Ecol. Prog. Ser.. 75. 239-249.

Greenwood J. G.. D. R. Fielder, M. J. Thorne, 1976. The larval life history of Macrobrachium nozuehollandiue (De Man, 1908) (Decapoda. Palaemonidae), reared in the laboratory. Crustaceana. 30. 252-286.

Guest W. C., 1979. Laboratory life history of the palaemonid shrimp Macrobrachium unazonicum (Heller) (Decapoda, Palaemonidae). Crustaceana, 37, 141-152.

Guzman M.. J. Cabrera. C. Kensler. 1977. Notes on Macrobrachium species in Mexico. Chapter II. In: Sprimp and Prawn Farming in the Western Hemisphere, J. A. Hanson and H. L. Goodwin eds.. Dowden. Hutchinson and Ross Inc.. Stroudsburg. Pennsylvania, 207-208.

Hanson J. A., H. L. Goodwin (eds.), 1977. Shrimp and prawn farming in the western hemisphere. Dowden. Hutchinson and Ross Inc.. Stroudsburg. Pennsylvania, 439 p.

Harrison K. E., P. L. Lutz, 1980: Studies on the ontogenesis of osmoregulation in Macrobrachium rosenbergii with application to shipping postlarvae. Proc. World Maricult. Soc., 11. 181-182.

Hartnoll R. G., R. Dalley, 1981. The control of size variation within instars of a crustacean. J. exp. mar. Biol. Ecol.. 53. 235-239.

Holthuis L. B.. 1951. The Caridean crustacea of tropical West Africa. Atlantide Rep.. 2, 7-187.

Hughes D. A., J. D. Richard. 1973. Some current-directed movements of Macrobrachium acanthurus (Wiegmann 1836) (Decapoda. Palaemonidae) under laboratory conditions. Ecology, 54, 927-929.

Jalihal D. R., 1992. Erroneous records of the Malayan riceland prawn Macrobrachium lanchesteri (de Man) from India-larval evidence (Decapoda, Caridea, Palaemonidae). Crustaceana, 62, 101-105.

Johns D. M., 1981. Physiological studies on Cancer irroratus larvae. I. Effects of temperature and salinity on survival. development rate and size. Mar. Ecol. Prog. Ser., 5. 75-83.

Johnson D. S., 1968. Biology of potentially valuable freshwater prawns with special reference to the riceland prawn Cryphiops (Macrobrachium) lanchesteri (de Man). FAO Fish. Rep.. 57, 233-241.

Katre S., T. J. Pandian, 1972. On the hatching mechanism of a freshwater prawn Macrobrachium idue. Hydrobiologia, 40, 1-17.

Kinne O., 1963. The effects of temperature and salinity on marine and brackish water animals. I. Temperature. Oceanogr. Mar. Biol. Ann. Rei.. 1, 301-340.

Kinne O., 1964. The effects of temperature and salinity on marine and brackish water animals. I1. Salinity and temperature-salinity combinations. Oceanogr. Mar. Biol. Am. Rei.. 2. 281-339.

Kinne O., 1966. Physiological aspects of animal life in estuaries with special reference to salinity. Neth. J. Seat Res. 3. 222-244.
Knowiton R. E.. 1974. Larval developmental processes and controlling factors in decapod Crustacea. with emphasis on Caridea. Thalassia Jugosluicica. 10. 139-158.

Kok Jee A.. L. Y. Kok, 1991. Fecundity changes in Macrobrachium rosenbergii (de $\mathrm{Man}$ ) during egg incubation. Aquac. Fish. Manage.. 22. 1-6.

Koroleff F.. 1970. Direct determination of ammonia in natural waters as indophenol blue. ICES Seri. Hrdrogr. Interlab. Rep.. 3. 4 p.

Kurata H.. 1962. Studies on the age and growth of crustacea. Bull. Hokkaido Reg. Fish. Res. Lab., 24, 1-115.

Lee C. L.. D. R. Fielder, 1981/1982. The effect of salinity and temperature on the larval development of the freshwater prawn. Macrobrachium australiense Holthuis. 1950 from south eastern Queensiand. Australia. Aquaculinre, 26, 167-172.

Lewis J. B.. J. Ward, 1965. Developmental stages of the Palaemonid shrimp Macrobrachium carcinus (Linnaeus, 1758). Crustaceana. 9, 137-148.

Ling S. W., A. B. O. Merican. 1961. Notes on the life and habits of the adults and larval stages of Macrobrachium rosenhergii (de Man). Proc. Indo-Pacif. Fish. Coun.. 9. 55-60.

Ling S. W., $1967 a$. Methods of rearing and culturing Macrobrachium rosenbergii (de Man). FAO Wld Sci. Conf. Biol. Shrimps and Prawns. Mexico City, 1224 June. 1967. Preprint FR: BCSP/67/E/31, $11 \mathrm{p}$.

Ling S. W.. $1967 \mathrm{~h}$. The general biology and development of Macrobrachium rosenbergii (de Man). FAO Wid Sci. Conf. Biol. Shrimps and Prawns. Mexico City, 1224 June. 1967. Preprint FR: BCSP/67/E/30. 18 p.

Ling S.W., $1969 a$. Methods of rearing and culturing Macrobrachium rosenbergii (de Man). FAO Fish. Rep., 57, 607-619.

Ling S. W., $1969 b$. The general biology and development of Macrobrachium rosenbergii (de Man). FAO Fish. Rep., 57. 589-606.

Lucas J. S., 1972. The larval stages of some Australian species of Halicarcinus (Crustacea, Brachyura, Hymeno. somatidae). II. Physiology. Bull. Mar. Sci., 22. 824-840.

Malecha S. R., 1983. Commercial pond production of the freshwater prawn, Macrobrachium rosenbergii, in Hawaii. In: CRC Handbook of Mariculture Vol. I, Crustacean Aquaculture, J. P. McVey, J. R. Moore eds., CRC Press. Inc., Boca Raton. Florida, 231-259.

McNamara J. C., G. S. Moreira. P. S. Moreira. 1980. Respiratory metabolism of Macrobrachium olfersii (Wiegmann) zoeae during the moulting cycle from eclosion to first ecdysis. Biol. Bull., 159. 692-699.

McNamara J. C., G. S. Moreira. P. S. Moreira, 1982. The effect of salinity on the respiratory metabolism and duration of intermoult cycle in larval and adult Macrobrachium olfersii (Wiegmann) (Decapoda. Palaemonidae). Bol. Fisiol. Animal, Uniz. S. Paulo, 6. 116-125.

McNamara J. C.. G. S. Moreira. P. S. Moreira. 1983. The effect of salinity on respiratory metabolism. survival and moulting in the first zoea of Macrobrachium amazonicum (Heller) (Crustacea. Palaemonidae). Hrdrobiologia. 101. $239-242$. 
McNamara J. C.. L. C. Salomão. E. A. Ribeiro. 1991. Neuroendocrine regulation of osmotic and ionic concentrations in the hemolymph of the freshwater shrimp Macrobrachium olfersii (Wiegmann) (Crustacea, Decapoda). Gen. Comp. Endocrinol., 84, 16-26.

Miyajima L. S., 1977. About Macrabrachium species. Chapter II. I $n$ : Sprimp and Prawn Farming in the Western Hemisphere, J. A. Hanson and H. L. Goodwin eds., Dowden, Hutchinson and Ross Inc., Stroudsburg, Pennsylvania, 201-206.

Miller G. C., 1971. Commercial fishery and biology of the fresh-water shrimp, Macrobrachium, in the Lower St. Paul River, Liberia, 1952-1953. U.S. Dept. Comm., National Oceanic and Atmospheric Administration, National Marine Fisheries Service, Spec. Sci. Rep. Fish., 626, $13 \mathrm{p}$.

Moller T. H.. 1978. Feeding behaviour of larvae and postlarvae of Macrobrachium rosenbergii (De Man) (Crustacea: Palaemonidae). J. exp. mar. Biol. Ecol., 35, 251-258.

Monaco G., 1975. Laboratory rearing of the larvae of the palaemonid shrimp Macrobrachium americanum (Bate).Aquaculture, 6, 369-375.

Montú M., K. Anger, C. Bakker, 1990. Variability in the larval development of Metasesarma rubripes (Decapoda. Grapsidae) reared in the laboratory. Neritica. Pontal do Sul. PR. 5, 113-128.

Moreira G. S., J. C. McNamara, P. S. Moreira, 1979. The combined effects of temperature and salinity on the survival and moulting of early zoeae of Macrobrachium holthuisi (Decapoda: Palaemonidae). Bol. Fisiol. Animal, Univ. Sã̃ Paulo, 3, 81-93.

Müller F., 1892. O camarão preto, Palaemon potiuna. Arch. Mus. Nat. Rio de Janeiro. 8, 179-206.

Muranaka M. S., 1977. About Macrobrachium species. Chapter II. In: Sprimp and Prawn Farming in the Western Hemisphere, J. A. Hanson and H. L. Goodwin eds., Dowden, Hutchinson and Ross Inc.. Stroudsburg, Pennsylvania, 209.

New M. B., S. Singholka, 1982. Freshwater prawn farming. A manual for the culture of Macrobrachium rosenbergii. FAO Fish. Tech. Pap., 225, 116 p.

New M. B., 1990. Freshwater prawn culture: a review. Aquaculture, 88, 99-143.

Pande J. N., 1984. Some ecological observations leading to a new source of seed of the freshwater prawn Macrobrachium rosenbergii (De Man) in Maharashtra. J. Bombay Nat. Hist. Soc., 81, 489-493.

Pandian T. J., S. Katre, 1972. Effect of hatching time on larval mortality and survival of the prawn Macrobrachium idae. Mar. Biol., 13, 330-337.

Pandian T.J., C. Balasundaram, 1982. Moulting and spawning cycles in Macrobrachium nobilii. In: Giant prawn farming, M. B. New ed., Developments in Aquaculture and Fisheries Science 10. Elsevier Scientific Publishing Company Amsterdam-Oxford-New York. 5971.

Passano L. M.. 1960. Molting and its control. In: The physiology of crustacea. Vol. 1. T. H. Wuterman ed.. Academic Press. New York. 473-536.
Perdue J. A.. R. Nakamura. 1976. The effect of salinity on the growth of Wacrobrachium rosenbergii. Proc. 7th Ann. Meeting World Mariculture Soc., 647-654.

Powell C. B., 1983. Fresh and brackish water shrimp of economic importance in the Niger Delta. In: Proc. Fish. Soc. Nigeria. Calabar. 25th-27th January 1982. E. O. Ita ed.. Kainji Lake Research Institute. New Bussa. Nigeria. 254-285.

Prah S. K.. 1977. A preliminary study of the pond-adapted freshwater prawns, (Macrobrachium species) in the Motorway Lake. a small man-made lake in the coastal savanna of Accra. Ghana. Inst. of Aquatic Biology. Tech. Rep., 80.

Prah S. K., 1982. Possibilities of pond culture of freshwater prawns in Ghana. West Africa. In: Giant Prawn Farming. M. B. New ed.. Developments in Aquaculture and Fisheries Science 10. Elsevier Scientific Publishing Company Amsterdam-Oxford-New York. 403-409.

Preston N., 1985. The effects of temperature and salinity on survival and growth of larval Penaeus plehejus. Meicipenaeus macleayi and $M$. bennettae. In: Second Aust. Nat. Prawn Sem., P. C. Rothlisberg. B. J. Hill. D. J. Staples eds., NPS2. Cleveland. Australia, 31-40.

Rabanal H. R.. 1982. The fishery for palaemonid species and the need and potential for their culture. In: Giant prawn farming. M. B. New ed.. Developments in Aquaculture and Fisheries Science 10. Elsevier Scientific Publishing Company Amsterdam-Oxford-New York. 309-331

Rajyalakshmi T.. 1961. Studies on maturation and breeding in some estuarine palaemonid prawns. Proc. Natl. Inst. Sci. India, Part B. Biol. Sci., 27. 179-188.

Ra'anan Z., A. Sagi, Y. Wax. I. Karplus, G. Hulata. A. Kuris, 1991. Growth. size. rank. and maturation of the freshwater prawn. Macrobrachium rosenbergii: Analysis of marked prawns in an experimental population. Biol. Bull., 181, 379-386.

Rasalan S. B., N. N. Delmendo. T. G. Reyes. 1969. Some observations of the biology of the freshwater prawn Macrobrachium lanceifions (Dana), with notes on the fishery. FAO Fish. Rep.. 57, 923-933.

Read G. H. L., 1985. Aspects of larval, post-larval and juvenile ecology of Macrobrachium petersi (Hilgendorf) in the Keiskamma estuary. South Africa. Estuar. Coast. Shelf Sci., 21, 501-510.

Reeve M. R.. 1969. The laboratory culture of the prawn Palaemon serratus. Fish. Iniest. Ser. II., 26. 1-38.

Rochanaburanon T.. D. I. Williamson, 1976. Laboratory survival of larvae of Palaemon elegans Rathke and other Caridean shrimps in relation to their distribution and ecology. Estuar. coast. mar. Sci.. 4, 83-91.

Rojas J., L. E. M. Silva, 1979. Estudio preliminar de Macrobrachium amazonicum (Heller). Conf'. Nac. Biol. Chicla!\%. Peru, 6, 163-164.

Romero M. E. de. 1982. Preliminary observations on potential of culture of Macrobrachium amazonicum in Venezuela. In: Giant prawn firming. M. B. New ed.. Developments in Aquaculture and Fisheries Science 10. Elsevier Scientific Publishing Company Amsterdam-Oxford-Now York. $411-416$. 
Rothlisberg P. C.. 1979. Combined effects of temperature and salinity on the survival and growth of the larvae of Pundalus jordani (Decapoda: Pandalidae). Mar. Biol.. 54. $125-134$

Rosenberg R.. J. D. Costlow Jr.. 1979. Delayed response to irreversible non-genetic adaptation to salinity in carly development of the brachyuran crab Rhithropanopeus harrisii and some notes on adaptation to temperature. Opinclica. 8. 97-112.

Rosenthal H.. K. R. Murray. 1986. System design and water quality criteria. In : Realism in aquaculture : Achievements, constraints. perspectives, M. Bilio. H. Rosenthal. C. J. Sindermann eds.. European Aquaculture Society. Bredene, $473-493$

Ruello N. V.. P. F. Moffitt. S. G. Phillips. 1973. Reproductive behaviour in captive freshwater shrimp Macrobrachium answaliense Holthuis. Aust. J. Mar. Freshwat. Res.. 24. 197-202.

Sandifer P. A.. J. S. Hopkins. T. I. J. Smith. 1975. Observations on salinity tolerance and osmoregulation in laboratory-reared Mucrobruchium rosenbergii postlarvae (Crustacea: Caridea). Aquaculture. 6. 103-114.

Sandifer P. A.. J. S. Hopkins. T. I. J. Smith, 1977. Status of Macrobrachium hatcheries. 1976. Chapter IV. Production of juveniles. In: Shrimp and Prawn Farming in the Western Hemisphere. J. A. Hanson and H. L. Goodwin eds.. Dowden. Hutchinson and Ross Inc. Stroudsburg. Pennsylvania. 220-231.

Sandifer P. A.. T. I. J. Smith. 1985. Freshwater prawns. In: Crustacean and Mollusk Aquaculture in the United States. J. V. Huner and E. E. Brown eds.. AVI Publishing Co.. Westport. CN.. 63-i25.

Scheliema R. S.. I. P. Williams. 1982. Significance of temperature to larval survival and length of development in Balanus eburneus (Crustacea: Cirripeda). Mar. Ecol. Prog. Ser.. 9. 43-49.

Shakuntala K.. 1977. The relation between body size and number of eggs in the freshwater prawn. Macrobrachium lamarrei (H. Milne Edwards) (Decapoda, Caridea). Crustaceana. 33. 17-22.

Shang Y.C.. 1972. Economic feasibility of freshwater prawn farming in Hawaii. Economic Research Center, Univ. Hawaii, Honolulu. Hawaii, 49 p.

Shokita S.. M. Takeda, S. Sittilert, T. Polpakdee, 1991. Abbreviated larval development of a fresh-water prawn, Macrobrachium niphanae Shokita and Takeda (Decapoda: Palaemonidae), from Thailand. J. Crust. Biol., 11 , 90-102.

Silverthorn S. S., 1975 a. Hormonal involvement in thermal acclimation in the fiddler crab Uca pugilator (Bosc). 1 . Effect of eyestalk extracts on whole animal respiratory. Comp. Biochem. Physiol., 50, 281-283.

Silverthorn. S. S.. 19756 . Hormonal involvement in thermal acclimation in the fiddler crab Uca pugilator (Bosc). II.
Effects of extracts on tissue respiration. Comp. Binchem. Phisiol.. 50. 285-290.

Silverthorn S. U.. A. M. Reese. 1978. Cold tolerance at threc salinities in post-larval prawns. Macrohrachium rosentergii (de Man). Acucculuture. 15. 249-255.

Singh T.. 1977. Osmotic and ionic regulation in Mccrohrerchium rosenbergii (de Man). 1879 (Decapoda: Caridea). M. Sc. Thesis. Univ. Malaya. Kuala Lumpur. 96 p.

Smitherman R. O.. D. D. Moss. E. L. Diaz. 1974. Observations on the biology of Macrohrachim annericanum Bate from a pond environment in Panama. Proc. 5th Ann. Workshop World Mariculture Soc.. 29-40.

Stephenson M. J.. A. W. Knight. 1980. The effect of temperature and salinity on oxygen consumption of postlarvae of Macrobiachium rosenbergii (de Man) (Crustacea: Palaemonidae). Comp. Biochem. Phisiol.. 67. 699. 703.

Takata M.. 1974. Development of the prawn culture industry in Hawaii. NTIS Ser. COM-75-10112. 26 p.

Templeman W.. 1936. The influence of temperature. salinity. light and food conditions on the survival and growth of the larvae of the lobster (Homarus americanus). J. Biol. Board Can.. 2, 485-497

Truesdale F. M.. W. J. Mermilliod. 1979. The river shrimp Macrobrachium ohione (Smith) (Decapoda. Palaemonidae): Its abundance. reproduction. and growth in the Atchafalaya River Basin of Louisiana. U.S.A. Crustaceana. 36. 61-73.

Udo P. J.. E. D. Ekpe. 1991. Fecundity in the African river prawn Macrobrachium iollenhoienii (Herklots 1857) from natural habitats. J. Aquac. Trop., 6. 173-177.

Uno Y.. Kwon Chin Soo. 1969. Larval development of Macrobrachium rosenbergii (de $\mathrm{Man}$ ) reared in the laboratory. J. Tokyo Uniz. Fish.. 55. 179-190 ((XIII Plates).

Wickins J. F., 1972 a. Developments in the laboratory culture of the common prawn. Palaemon serratus Pennant. Fish. Iniest., 27, Ser. II. 23 p.

Wickins J. F., 1972 b. Experiments on the culture of the spot prawn Pandalus platyceros Brandt and the giant freshwater prawn Macrobrachium rosenbergii (de Man). Fish. Iniest.. 27. Ser. II. 23 p.

Williamson D. I.. 1982. Larval morphology and diversity. In: The Biology of Crustacea. D. E. Bliss ed., Vol. 2 : Embryology, morphology, and genetics. L. G. Abele ed.. Academic Press, New York. London. 43-110.

Zabi G. S. F.. P. Le Loeuff. 1992 in press. Revue des connaissances sur la faune benthique des milieux margino-littoraux (1) d'Afrique de l'Ouest première partie: les espèces, Rei. Hydrobiol. Trop., 25.

Zanders I. P., J. M. Rodriguez. 1992. Effects of temperature and salinity stress on osmoionic regulation in adults and an oxygen consumption in larvae and adults of Macrobrachium anazonicum (Decapoda. Palaemonidae). Comp. Biochem. Physiol.. 101A, 505-509. 
